Arkivoc

Free to Authors and Readers
A Platinum Open Access Journal for Organic Chemistry

Review

DOAJ Seal

Arkivoc 2021, part ix, 150-176

\title{
A short review on synthetic strategies towards quinazoline based anticancer drugs
}

\author{
Vijay Kumar Sharma, ${ }^{* a, b}$ Anup Barde, ${ }^{* b}$ and Sunita Rattan*a \\ ${ }^{a}$ Amity Institute of Applied Sciences, Amity University Uttar Pradesh, Sector-125, Noida, India \\ ${ }^{b}$ Integral BioSciences Pvt. Ltd. C-64, Hosiery Complex, Phase-II Noida Uttar Pradesh, India \\ Email: vk.sharma@ibs.net.in, srattan@amity.edu, anup.barde@ibs.net.in
}

Received 05-06-2021

Accepted 06-11-2021

Published on line 08-03-2021

\section{Abstract}

Quinazolines belong to one of the most important classes of heterocyclic compounds owing to their diverse medicinal properties. The synthesis of novel quinazoline derivatives has been a main focus of many researchers during last decades due to the broad scope of this moiety. There are many commercial drugs available with a quinazoline motif and several compounds are in the preliminary development of potential bioactive compounds. This motif is being utilized in drug targets for the treatment of various diseases owing to the anti-cancer, anti-bacterial, anti-inflammatory, anti-malarial and anti-hypertensive activities. This review describes some of synthetic strategies used for manufacturing aminoquinazoline based anticancer drugs on both bench and industrial scales.

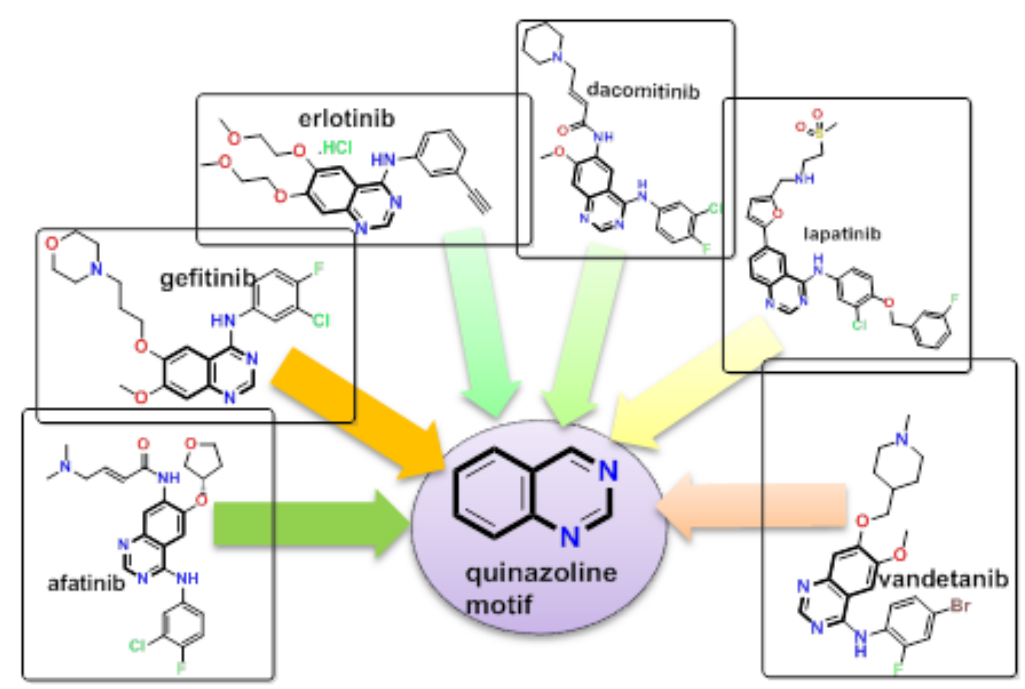

Keywords: Quinazoline, epidermal growth factor receptor (EGFR), anti-cancer drugs, Dimroth Rearrangement 


\section{Table of Contents}

1. Introduction

2. Quinazoline Derivatives as Drug Target

3. Quinazoline Moiety as Anti-cancer Drug Target

4. Synthetic Strategies Towards Quinazoline Based Anticancer Drugs

4.1. Afatinib (Gilotrif ${ }^{\circledast}$, Giotrif $^{\circledast}$, Afanix ${ }^{\circledR}$ - Boehringer Ingelheim Pharmaceuticals, Inc.)

4.1.1. Synthesis of Afatinib (A)

4.2. Gefitinib (Iressa ${ }^{\circledR}$ - AstraZeneca Pharmaceuticals)

4.2.1. Synthesis of gefitinib (G)

4.3. Erlotinib (Tarceva ${ }^{\circledR}$ - Roche Pharmaceuticals)

4.3.1. Synthesis of Erlotinib (E)

4.4. Dacomitinib (Vizimpro ${ }^{\circledR}$ - Pfizer Inc.)

4.4.1. Synthesis of dacomitinib (D)

4.5. Lapatinib (Tykerb ${ }^{\circledR}$ and Tyverb ${ }^{\circledR}$ - GlaxoSmithKline (GSK))

4.5.1. Synthesis of Lapatinib (L)

4.6. Vandetanib (Caprelsa ${ }^{\circledR}$ - AstraZeneca)

4.6.1. Synthesis of vandetanib (V)

4.7. Future Perspective of Quinazoline Based Heterocyclic Compounds

5. Conclusions

Acknowledgements

References

\section{Introduction}

Examining practices of medicinal chemistry is enriching as well as challenging. A definitive objective is the advancement of drugs in various therapeutic areas and understanding their mechanism of action. Despite the discovery of many selective and potent drugs that prevent diseases, alleviate pain, and manage the treatment of diseases afflicting humans, challenges to invent safer and efficacious drug molecules still remains. ${ }^{1}$ With the development of new tools to expedite drug discovery, the role of organic chemists to synthesize novel drug molecules of biological importance is pivotal to treat various diseases. Organic compounds specifically heterocyclic compounds are of paramount importance as more than half of all known organic compounds are heterocyclic. Synthesis of novel heterocycles in the laboratory has revolutionized the course of medical science. There are many classes of heterocyclic compounds which are being used as drugs for relief from various diseases. It has been observed that compounds containing heterocycles such as pyridine, pyrimidine, indole, thiazolidine-2,4-dione (TZD) and quinazoline etc. are central to the core of many therapeutic drugs.

\section{Quinazoline Derivatives as Drug Target}

The synthesis of quinazoline itself was first reported by Gabriel in 1903. The presence of a fused benzene ring alters the properties of the pyrimidine ring considerably. The properties of substituted quinazolines largely depend on the nature of the substituents and whether they are on the pyrimidine ring or on the benzene ring. ${ }^{2}$ Quinazoline derivatives are the central core of many complex natural products, which have been isolated from different plants and microorganisms. ${ }^{3,4}$ The quinazoline motif is pivotal in medicinal chemistry 
due to its diverse biological properties such as the anti-cancer, anti-bacterial, anti-inflammatory, anti-malarial, anti-convulsant and anti-hypertensive activities. ${ }^{5-6}$ Biological activities of quinazoline derivatives are very well established and there are numerous drugs available in the marketplace (Figure 1). This review summarizes the synthetic strategies which have been utilized for aminoquinazoline based commercial anti-cancer drugs on both bench and industrial scales. Though it has been our effort to compile all relevant work, there may be additional references that we have inadvertently missed.

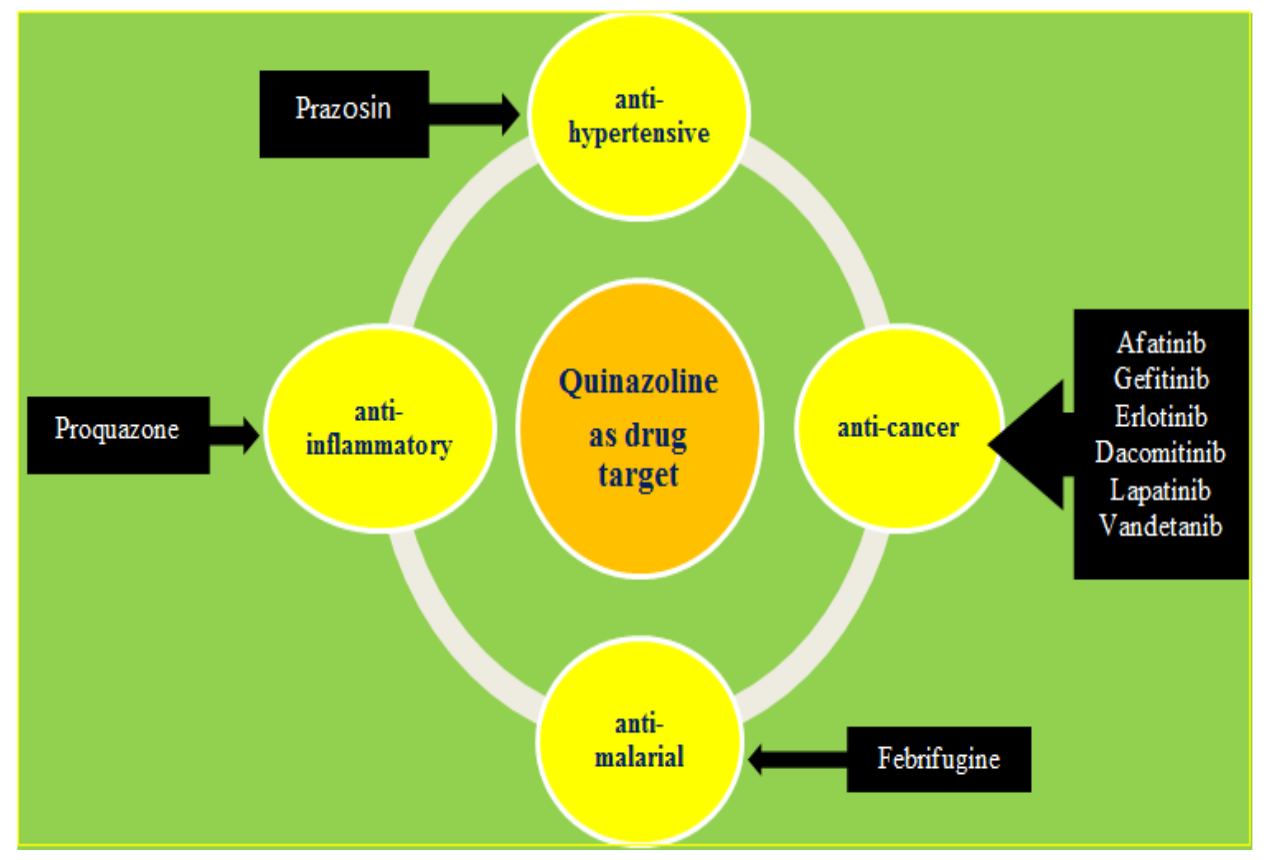

Figure 1. Summary of quinazoline based drugs.

\section{Quinazoline Moiety as Anti-cancer Drug Target}

There has been a considerable development of promising quinazoline derivatives for cancer treatment during the last few decades. These are well known to inhibit epidermal growth factor receptor (EGFR) protein, albeit that a large panel of other therapeutic protein targets is also there. ${ }^{7}$ EGFR is a member of the tyrosine kinase receptor family. It is a cell membrane receptor which has an extracellular ligand binding domain and an intracellular tyrosine kinase domain. These trans-membrane receptors bind to ligands which lead to the homoor hetero dimerization of the receptor, which results in trans-phosphorylation of tyrosine residues. These downstream signaling pathways regulate cell division, motility, adhesion and apoptosis. It has been observed that high levels of EGFR expression are present in many tumor cells. ${ }^{8,9}$

A number of quinazoline derivatives have been approved by the FDA and novel quinazoline derivatives are being investigated as anti-cancer drugs from last two decades. Some of the clinically approved quinazoline derivatives have been depicted in Figure 2. Synthesis of these drug targets from medicinal chemistry scale to efficient, commercially viable and multi-gram scale preparations has been a challenging and thoughtful journey for synthetic chemists. We will describe the synthetic strategies involved for these aminoquinazolines in the following sections of this article. 


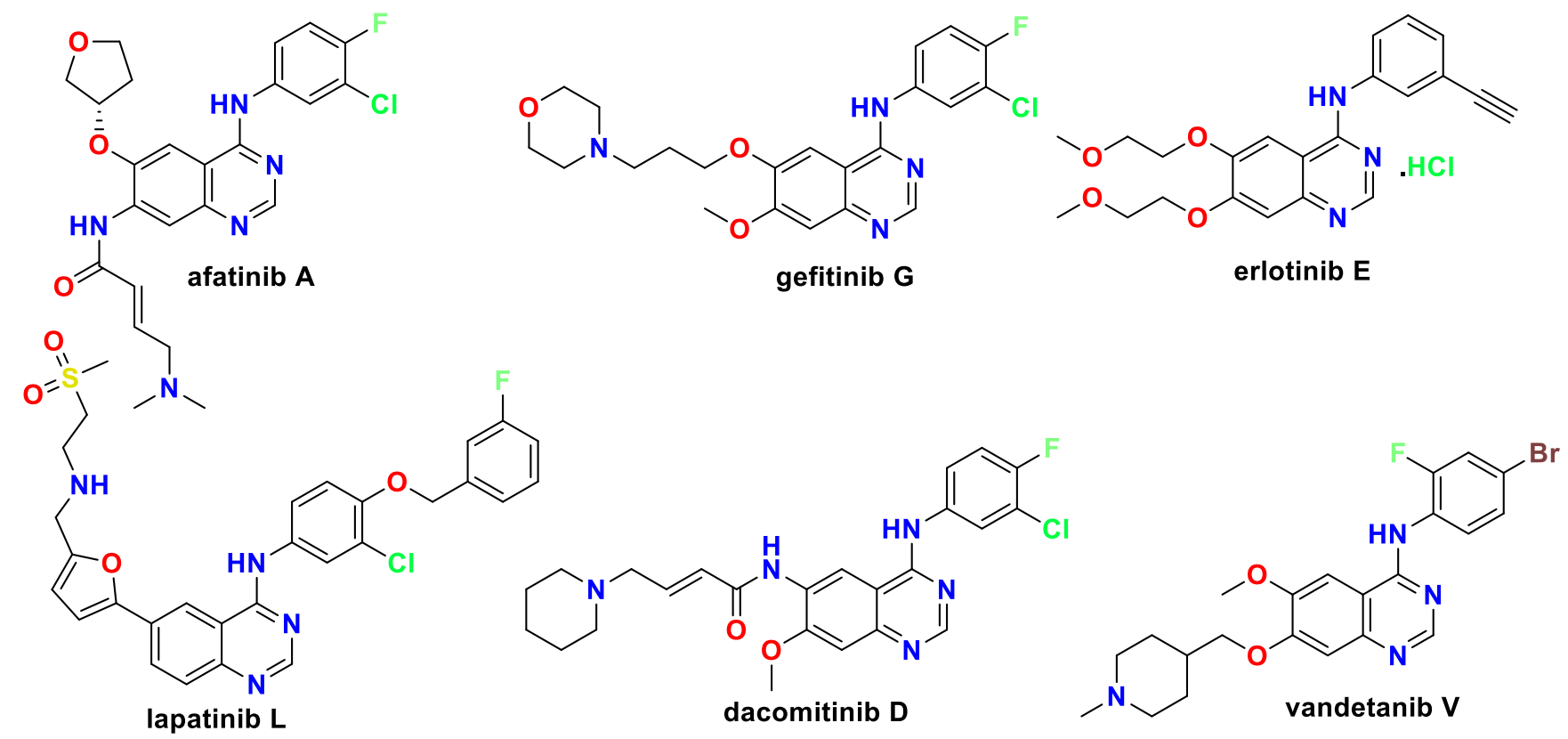

Figure 2. Quinazoline derivatives approved by the FDA as anti-tumor agent.

\section{Synthetic Strategies Towards Quinazoline Based Anticancer Drugs}

Synthetic strategies utilized for synthesis of quinazoline based anticancer drugs is discussed in subsequent sections:

\subsection{Afatinib (Gilotrif ${ }^{\circledR}$, Giotrif $^{\circledR}$, Afanix $^{\circledR}$ - Boehringer Ingelheim Pharmaceuticals, Inc.)}

Afatinib (A) (Figure 3) is a medication which has been used for metastatic non-small cell lung carcinoma (NSCLC). ${ }^{10}$ It is an irreversible inhibitor of epidermal growth factor receptor (EGFR) and human epidermal receptor (HER2) tyrosine kinases. ${ }^{11}$ It is the first lung cancer treatment drug. The drug passed the fast-track approval channel of the US FDA in 2008. It was approved as drug in $2013 .{ }^{12}$

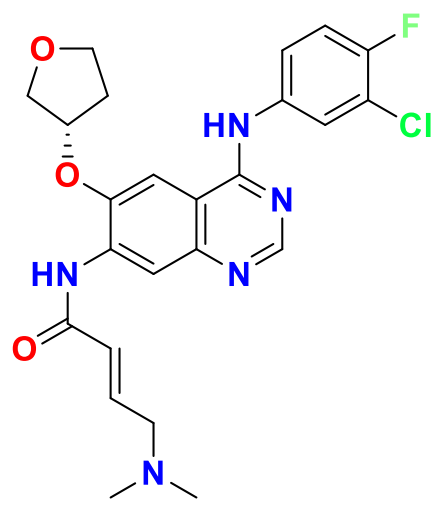

Figure 3. Chemical structure of Afatinib (A).

4.1.1. Synthesis of Afatinib (A). The first reported synthesis of $\mathbf{A}$ involved the synthesis from the advanced intermediate $\mathbf{A} \mathbf{1}$ which reacts with the hydroxy group of S-tetrahydrofuran-3-ol $\mathbf{A} \mathbf{2}$ in the presence of potassium tert-butoxide to form intermediate $\mathbf{A} 3$. The nitro group at the 6-position in $\mathbf{A} 3$ is reduced with iron 
to afford compound $\mathbf{A 4}$. The compound $\mathbf{A} 4$ undergoes amidation reaction with (E)-4-bromobut-2-enoic acid chloride to obtain intermediate $\mathbf{A} \mathbf{6}$ which after amination reaction with $\mathbf{A} 6$ and dimethylamine, afforded $\mathbf{A}$ (Scheme 1). ${ }^{13,14}$

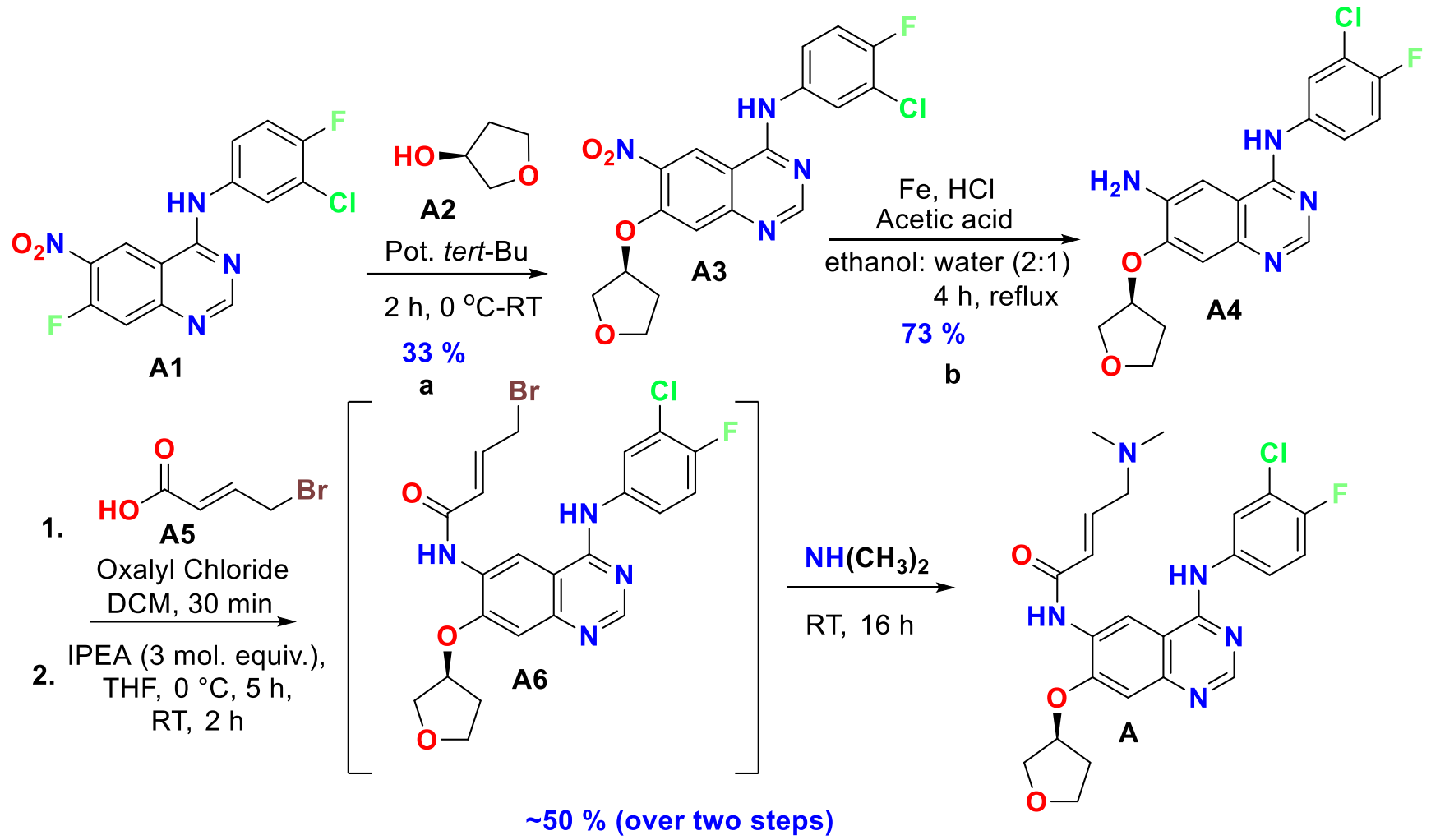

Reagents and conditions: a) (S)-tetrahydrofuran-3-ol A2 (1 mol. equiv.), potassium tert-butoxide (6 mol. equiv.), DMF, $0{ }^{\circ} \mathrm{C}-\mathrm{RT}, 2 \mathrm{~h}$; b) Fe (4 mol. equiv.), acetic acid ( 9.3 mol. equiv.), ethanol:water (2:1), reflux, $\left.4 \mathrm{~h} ; \mathrm{c}\right)$ i) (E)-4-bromobut-2-enoic acid (1.5 mol. equiv.), oxalyl chloride (47 mol. equiv.) DMF (1-2 drops), DCM, 30 min.; ii) DIPEA ( 3 mol. equiv.), THF, $0{ }^{\circ} \mathrm{C}, 5 \mathrm{~h}, \mathrm{RT}, 2 \mathrm{~h}$; iii) Dimethyl amine, $\mathrm{RT}, 16 \mathrm{~h}$

Scheme 1. Initial synthesis of Afatinib (A).

Since this synthetic strategy first prepares the quinazoline core and then performs the side chain attachments, the overall yield is low and most steps need to be purified by column chromatography. Therefore, this synthetic approach is not suitable for an industrial scale synthesis.

Xuenon et al. reported a preparation method that has easy-to-obtain raw materials, is a simple process, is economical and ecofriendly. This approach is advantageous for the industrial production of the drug (Scheme 2). ${ }^{15}$ The process involves nitration of $p$-hydroxybenzonitrile $\mathbf{A 7}$ in the presence of nitric acid and sulphuric acid to form 4-hydroxy-3-nitrobenzonitrile A8. Reaction of S-tetrahydrofuran-3-ol A2 with $\mathbf{A} 8$ in the presence of DIAD yielded the corresponding ether compound $\mathbf{A} \mathbf{9}$. Reduction of the nitro group of $\mathbf{A} \mathbf{9}$ using $\mathrm{FeCl}_{3}$ afforded the corresponding amine $\mathbf{A 1 0}$ in good yield. A10 and E-4-(dimethylamino)but-2-enoyl chloride $\mathbf{A} 11$ undergo amidation to produce $\mathbf{A 1 2}$. Nitration of $\mathbf{A} 12$ afforded $\mathbf{A} 13$ which was reduced in the presence of $\mathrm{Pd} / \mathrm{C}$ to form amine A14. Cyclization followed by amination of A14 afforded Afatinib A. This process involves classical reactions and easily available starting materials, which are suitable for industrial scale synthesis. 


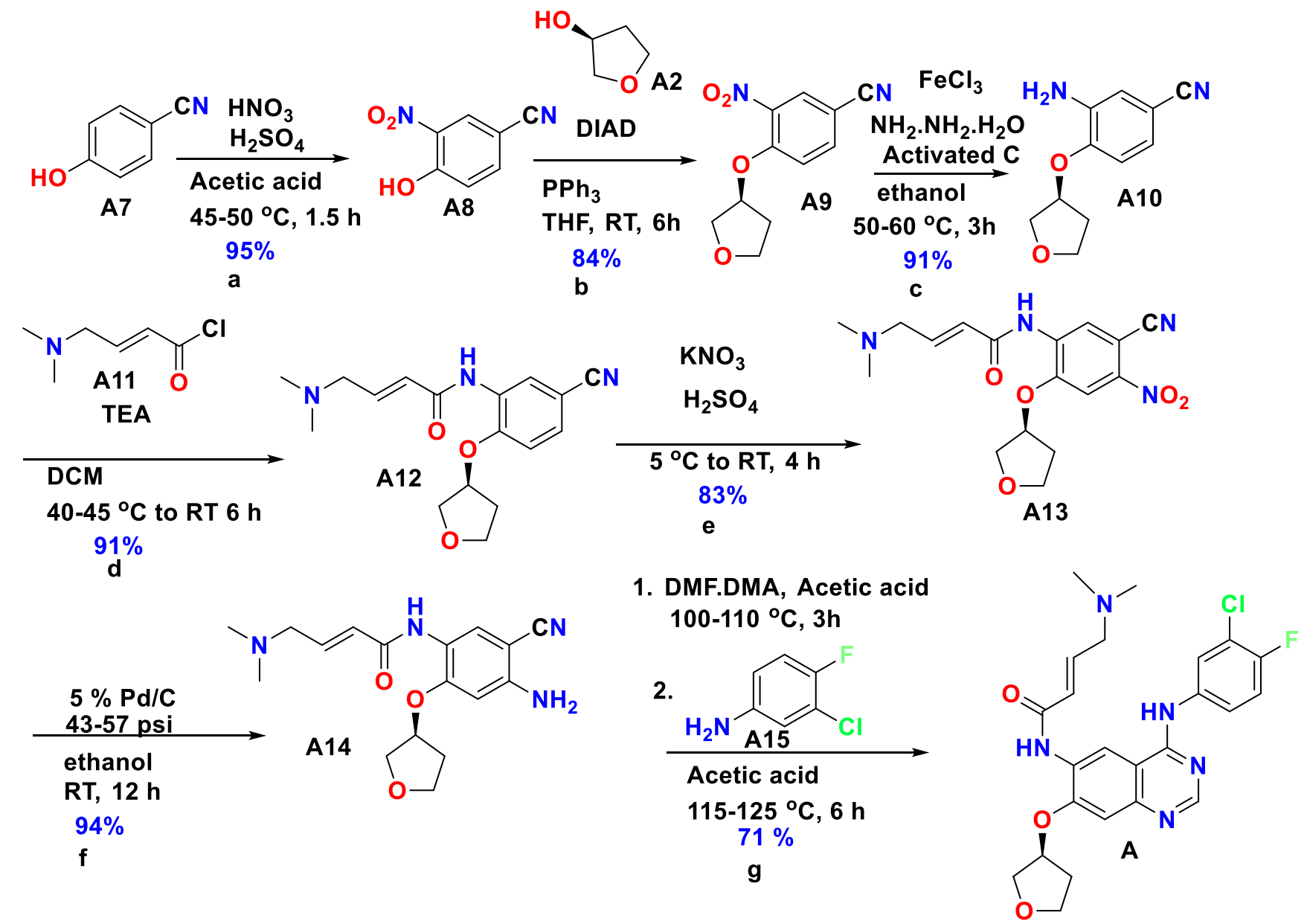

Reagents and conditions: a) $\mathrm{HNO}_{3}$ (2 mol. equiv.), Conc. $\mathrm{H}_{2} \mathrm{SO}_{4}$ (2 mol. equiv.), acetic acid, $45-50{ }^{\circ} \mathrm{C}, 1.5 \mathrm{~h}$; b) DIAD (3 mol. equiv.), triphenylphosphine (3 mol. equiv.), (S)-tetrahydrofuran-3-ol A2 (1.1 mol. equiv.), THF, $\mathrm{RT}, 4 \mathrm{~h}$; c) $\mathrm{FeCl}_{3}$ (4 mol. equiv.), Activated carbon (9.3 mol. equiv.), ethanol, 50-60 ${ }^{\circ} \mathrm{C}, 3 \mathrm{~h}, 80 \%$ hydrazine hydrate; d) (E)-4-(dimethylamino)but-2-enoyl chloride A11 (1.1 mol. equiv.), TEA (1.1 mol. equiv.), 40-45 ${ }^{\circ} \mathrm{C}$ to $\mathrm{RT}, 6 \mathrm{~h}$; e) $\mathrm{KNO}_{3}$ (2 mol. equiv.), $\mathrm{H}_{2} \mathrm{SO}_{4}$ (33 mol. equiv.), $5{ }^{\circ} \mathrm{C}$ to $\mathrm{RT}, 4 \mathrm{~h}$; f) $5 \% \mathrm{Pd} / \mathrm{C}(10 \% \mathrm{w} / \mathrm{w}), 43-57 \mathrm{psi}$, hydrogen, ethanol, RT, $12 \mathrm{~h}$; g) i) DMF.DMA (1.5 mol. Equiv.), Acetic acid (1.8 mol. Equiv.), toluene, $100-110{ }^{\circ} \mathrm{C}$, 3h ii) 3-chloro-4-fluoroaniline (1.4 mol. Equiv.), acetic acid, $115-125{ }^{\circ} \mathrm{C}, 6 \mathrm{~h}$.

Scheme 2. Industrial scale synthesis of Afatinib (A).

\subsection{Gefitinib (Iressa ${ }^{\circledR}$ - AstraZeneca Pharmaceuticals)}

Gefitinib (Fig 4) is a drug used in the treatment of certain types of cancer including breast, lung and other. It selectively targets the mutant proteins in malignant cells. Gefitinib is the first selective inhibitor of EGFR tyrosine kinase (TK) domain. It inhibits the intracellular phosphorylation of numerous tyrosine kinases associated with trans-membrane cell surface receptors, including the EGFR-TK. ${ }^{16}$

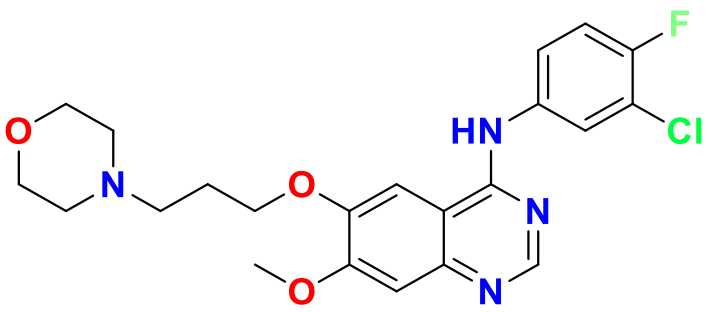

Figure 4. Chemical structure of gefitinib (G). 
4.2.1. Synthesis of gefitinib (G). The initial synthesis of gefitinib (G) as depicted in the literature ${ }^{17,} 18$ involved the synthesis from 2-amino-4,5-dimethoxybenzoic acid $\mathbf{G 1}$ with formamide $\mathbf{G 2}$ to afford 6,7dimethoxyquinazolin-4(3H)-one G3. G3 undergoes a demethylation reaction in the presence of L-methionine and methanesulfonic acid to form intermediate $\mathbf{G 4}$. The acetylation of $\mathbf{G} 4$ followed by chlorination afforded G5 and G6; respectively. Amination of $\mathbf{G 6}$ with 4-chloro-3-fluoroaniline $\mathbf{G 7}$ in propan-2-ol under reflux conditions afforded intermediate $\mathbf{G 8}$ which was de-methylated in presence of liquor ammonia to form $\mathbf{G 9}$. The reaction of $\mathbf{G 9}$ and 4-(3-chloropropyl)morpholine $\mathbf{G 1 0}$ in the presence of potassium carbonate and $N, N$ dimethyl formamide (DMF) yielded G. (Scheme 3)

This synthetic methods for the preparation of gefitinib $\mathbf{G}$ involves the construction of substituted quinazolin-4(3H)-ones from 2-amino-4,5-dimethoxybenzoic acid G1. The yield and methodology improved to $98 \%$ by Knesl et al by simply increasing the de-methylation step by $16 \mathrm{~h}$. ${ }^{19}$ However, preparation by this method involves the use of corrosive chemicals such as thionyl-chloride, high temperature reaction conditions and poor yields in some of the other steps.

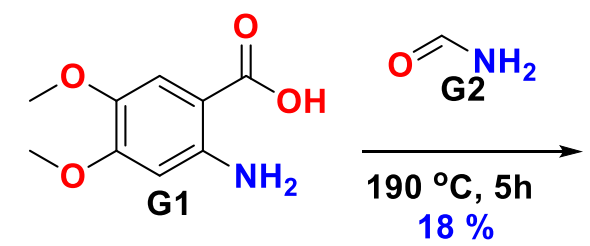

a

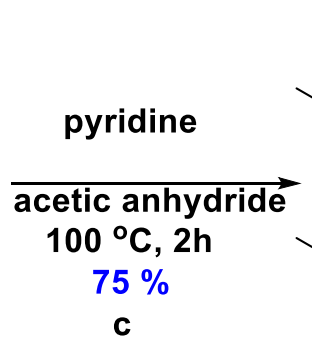

C<smiles>COc1cc2nc[nH]c(=O)c2cc1OC(C)=O</smiles><smiles>COc1cc2nc[nH]c(=O)c2cc1OC</smiles>

G3

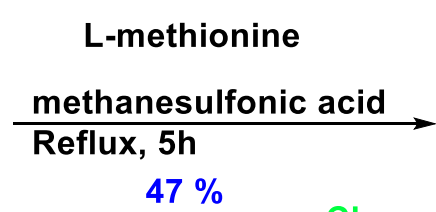

b

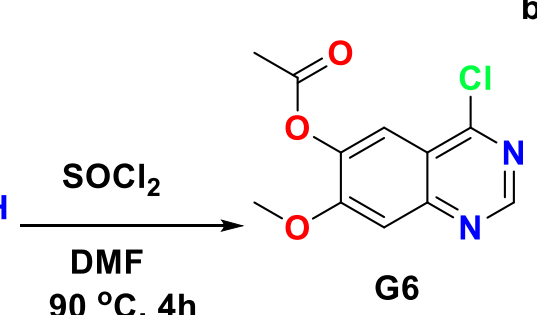

$90^{\circ} \mathrm{C}, 4 \mathrm{~h}$

$56 \%$ (over 2 steps)

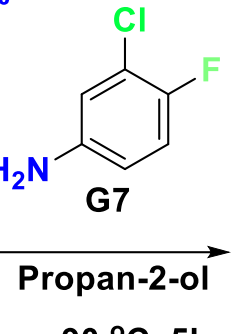

$90^{\circ} \mathrm{C}, 5 \mathrm{~h}$<smiles>COc1cc2nc[nH]c(=O)c2cc1O</smiles>

G4<smiles>COc1cc2ncnc(Nc3ccc(F)c(Cl)c3)c2cc1OC(C)=O</smiles>

G8<smiles>COc1cc2ncnc(Nc3ccc(F)c(Cl)c3)c2cc1OCCCN1CCOCC1</smiles>

Reagents and conditions: a) formamide (2.5 mol. equiv.), $190{ }^{\circ} \mathrm{C}, 1.5 \mathrm{~h}$; b) L-methionine (1.2 mol. equiv.), methanesulfonic acid (21 mol. equiv.), Reflux, $5 \mathrm{~h}$; c) acetic anhydride (16 mol. equiv.), pyridine (2.4 mol. equiv.), $100{ }^{\circ} \mathrm{C}$, $2 \mathrm{~h}$; d) $\mathrm{SOCl}_{2}$ (46 mol. equiv.), DMF (0.9 mol. equiv.), $90{ }^{\circ} \mathrm{C}, 4 \mathrm{~h}$; e) 4-chloro-3-fluoroaniline $\mathrm{G} 7$ (1 mol. equiv.), propan-2ol, $90{ }^{\circ} \mathrm{C}, 4 \mathrm{~h}$; f) Liquor ammonia (30\% w/v) (1.6 mol. equiv.), methanol, $100{ }^{\circ} \mathrm{C}, 1.5 \mathrm{~h}$; g) 4-(3-chloropropyl)morpholine (1.1 mol. Equiv.), $\mathrm{K}_{2} \mathrm{CO}_{3}\left(3.4\right.$ mol. equiv.), $\mathrm{DMF}, 80^{\circ} \mathrm{C}, 1 \mathrm{~h}$.

Scheme 3. Synthesis of gefitinib (G).

To overcome these difficulties, a one-pot synthesis of quinazolin-4(3H)-ones under mild reaction conditions has been reported. ${ }^{20}$ This approach (Scheme 4) uses the isovanillin $\mathbf{G 1 1}$ which was alkylated with 4(3-chloropropyl)morpholine G12 to form 4-methoxy-3-(3-morpholinopropoxy)benzaldehyde G13 in good yield. 
The conversion of $\mathbf{G 1 3}$ to nitrile $\mathbf{G 1 7}$ is achieved with a reasonably high yield through the formation of an oxime intermediate $\mathbf{G 1 5}$. The synthesis of quinazoline $\mathbf{G 1 9}$ was performed by reacting ortho-nitrobenzonitrile G18 with a reducing agent such as $\mathrm{FeCl}_{3} / \mathrm{N}_{2} \mathrm{H}_{4} \cdot \mathrm{H}_{2} \mathrm{O}$ and in situ cyclisation with $\mathrm{HCl}$-formic acid. Chlorination followed by amination with 4-chloro-3-fluoroaniline $\mathbf{G 7}$ yielded gefitinib (G) in good yields.

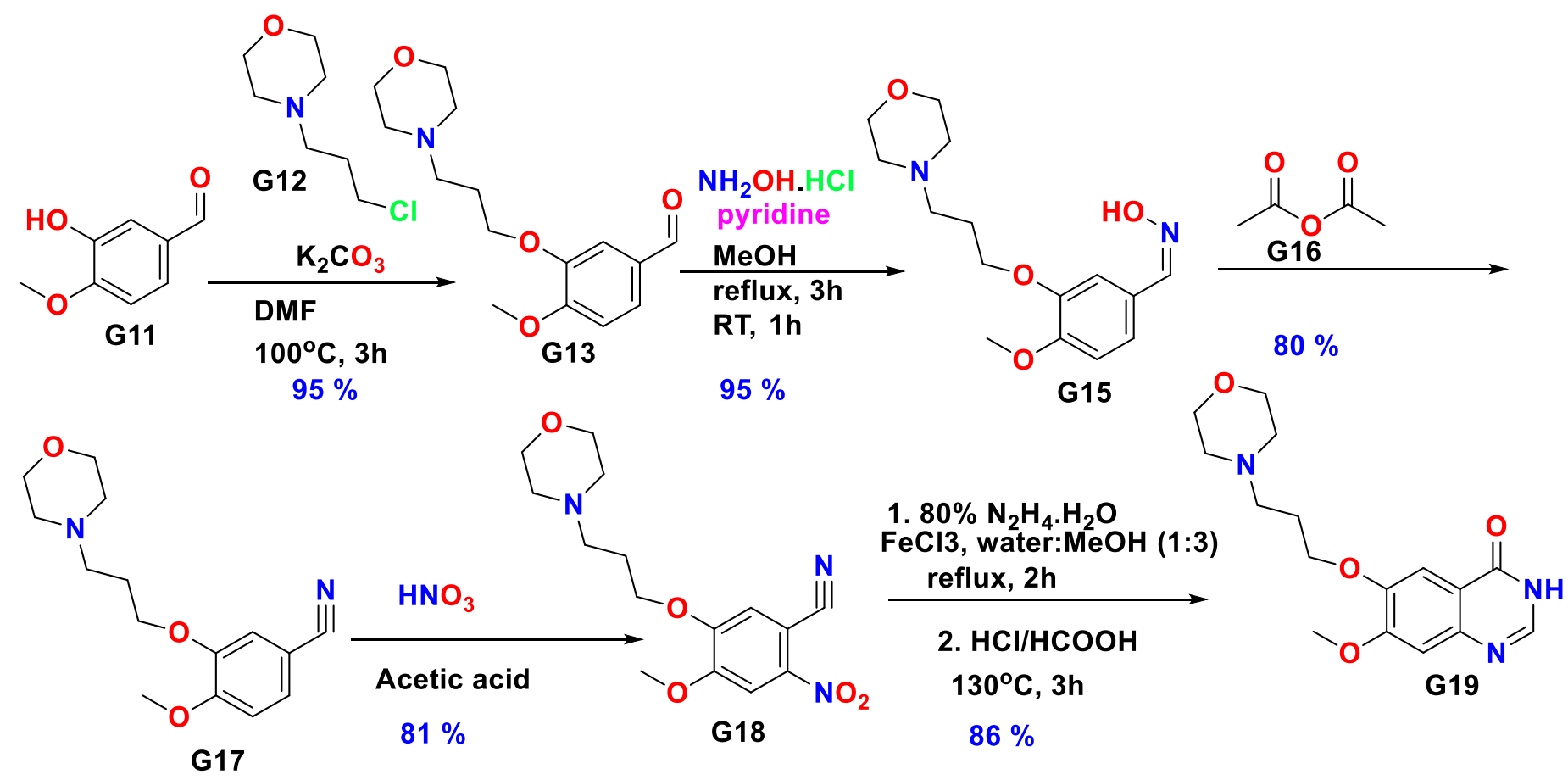

1. $\mathrm{SOCl}_{2}$, DMF

reflux, $2 \mathrm{~h}$; dist. off $\mathrm{SOCl}_{2}$

2.<smiles>Nc1ccc(F)c(Cl)c1</smiles><smiles>COc1cc2ncnc(Nc3ccc(F)c(Cl)c3)c2cc1OCCCN1CCOCC1</smiles>

DMF

$100^{\circ} \mathrm{C}, 3 \mathrm{~h}$

$73 \%$

Reagents and conditions: a) 4-(3-chloropropyl)morpholine $\mathbf{G 1 2}$ (1.1 mol. equiv.), $\mathrm{K}_{2} \mathrm{CO}_{3}$ (2 mol. equiv.), DMF, $100{ }^{\circ} \mathrm{C}, 3 \mathrm{~h}$; b) $\mathrm{NH}_{2} \mathrm{OH} . \mathrm{HCl}$ (2 mol. equiv.), pyridine (2 mol. equiv), $\mathrm{MeOH}$, reflux, $1 \mathrm{~h} ; \mathrm{c}$ ) acetic anhydride $\mathbf{G 1 6}$ (6.34 mol. equiv.), $110{ }^{\circ} \mathrm{C}, 3 \mathrm{~h}$; d) $\mathrm{HNO}_{3}\left(70 \%, 4\right.$ mol. equiv.), acetic acid (1.4 vol.), $45-50{ }^{\circ} \mathrm{C}, 8 \mathrm{~h}$; e) i) $\mathrm{FeCl}_{3}$ (0.006 mol. equiv.), $80 \%$ hydrazine hydrate (4.7 mol. equiv.), water: $\mathrm{MeOH}(1: 3)$, reflux, $3 \mathrm{~h}$; ii) $35 \% \mathrm{HCl}(6 \mathrm{~mol}$. equiv.), formic acid ( 2.3 mol. equiv.), $130{ }^{\circ} \mathrm{C}, 3 \mathrm{~h}$; f) i) $\mathrm{SOCl}_{2}\left(27\right.$ mol. equiv.), $\mathrm{DMF}\left(0.42 \mathrm{~mol}\right.$. equiv.), $100{ }^{\circ} \mathrm{C}, 1$ $\mathrm{h}$ - distilled off thionyl chloride; ii) 4-chloro-3-fluoroaniline $\mathbf{G 7}\left(27\right.$ mol. equiv.), DMF, $100{ }^{\circ} \mathrm{C}, 1 \mathrm{~h}$.

Scheme 4. Industrial scale synthesis of gefitinib (G).

Chandregowda et al. later reported an improved convergent approach for commercial synthesis of G. ${ }^{21}$ The convergent process (Scheme 5) developed for the preparation of gefitinib involves reducing nitro group of ortho-nitrobenzonitrile $\mathbf{G 1 8}$ with $\mathrm{Na}_{2} \mathrm{~S}_{2} \mathrm{O}_{4} \cdot \mathrm{H}_{2} \mathrm{O}$ to form $\mathbf{G 1 9}$. $\mathbf{G 1 9}$ is reacted with DMF.DMS to synthesize $N^{\prime}-2-$ 
cyano-4,5-\{bis(2-methoxyethoxy)phenyl\}- $N, N$-dimethylformamidine $\mathbf{G 2 0}$ which was further reacted by 3chloro-4-fluoroaniline $\mathbf{G 7}$ to get gefitinib $(\mathbf{G})$. This process permits a reduction in the number of steps used and with higher yields.

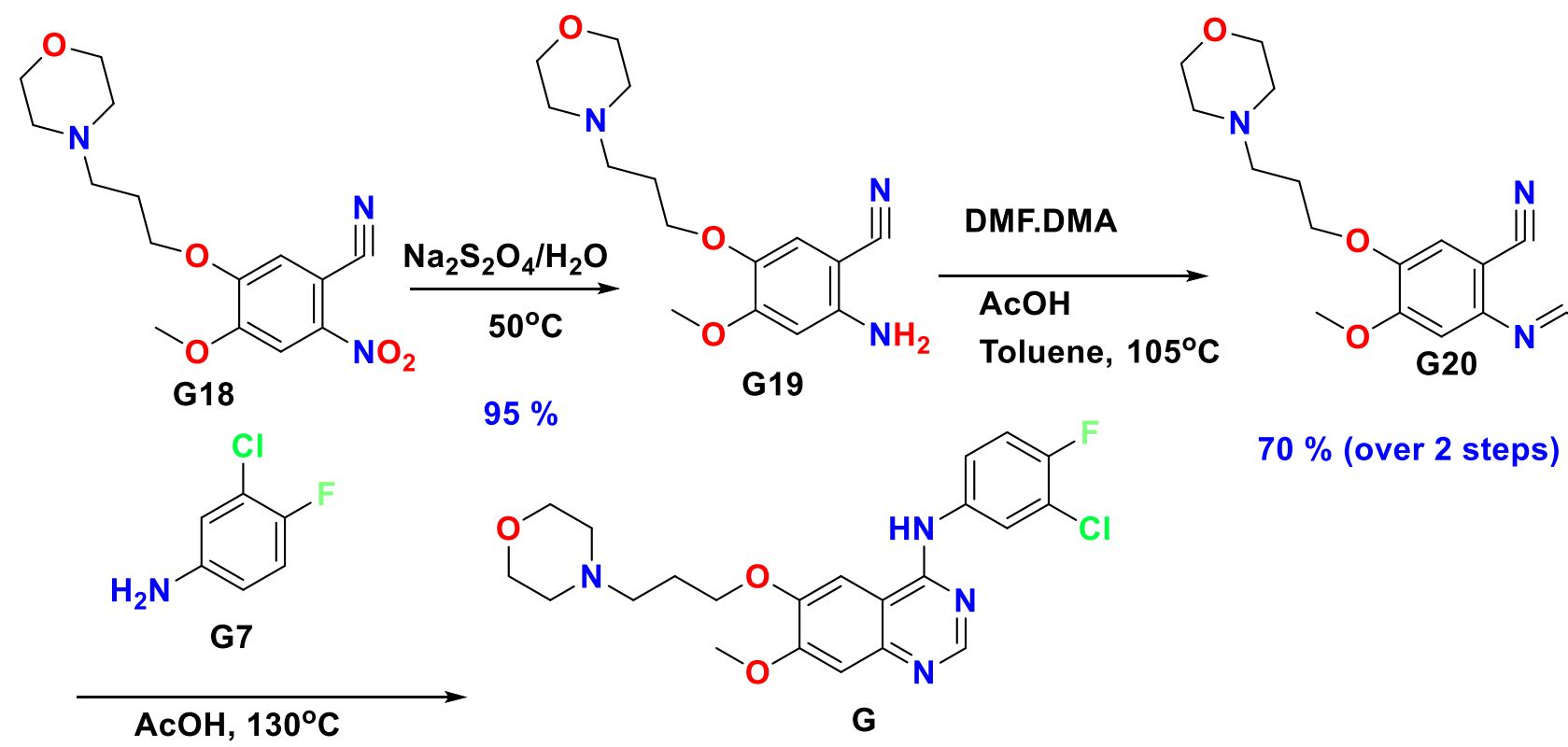

Reagents and conditions: a) i) sodium dithionite (3.3 mol. Equiv.), water, $50{ }^{\circ} \mathrm{C}, 2.5 \mathrm{~h}$; ii) $25 \% \mathrm{HCl}(5 \mathrm{vol} . \mathrm{w} / \mathrm{w})$, $70{ }^{\circ} \mathrm{C}$, addition over a period $2.5 \mathrm{~h}$ b) i) DMF.DMA (2.2 mol. Equiv.), Acetic acid ( 0.05 mol. equiv.), toluene, 105 ${ }^{\circ} \mathrm{C}$, dean-stark apparatus, $3 \mathrm{~h}$ ii) 3-chloro-4-fluoroaniline $\mathbf{G 7}\left(1.2 \mathrm{~mol}\right.$. Equiv.), acetic acid,125-130 ${ }^{\circ} \mathrm{C}, 3 \mathrm{~h}$.

Scheme 5. Industrial scale synthesis of gefitinib (G).

M. Chandrasekhar et al. reported a convenient and easy purification approach to high-yield synthesis of $\mathbf{G}$ from isovaniline (Scheme 6). ${ }^{22}$ In this approach, nitrile $\mathbf{G} 25$ was treated with $30 \% \mathrm{H}_{2} \mathrm{O}_{2}$ in ethanol solution to the corresponding amide G26. Reduction of intermediate G26, was carried out using Fe in AcOH to afford G27. Cyclization of the $\mathbf{G} \mathbf{2 7}$ to the corresponding quinazolin-4(3H)-one derivative $\mathbf{G} \mathbf{2 8}$ was accomplished using formamide and formic acid. Further, 6-(3-chloropropoxy)-7-methoxy quinazoline-4(3H)-one G28 was reacted with $\mathrm{SOCl}_{2}$ in $\mathrm{CHCl}_{3}$ to give 4-chloro-7-methoxy-6-(chloropropoxy)quinazoline $\mathbf{G} 29$ which was reacted in situ with excess of 3-chloro-4-fluoroaniline to result $\mathbf{G 2 1}$ in an excellent yield. $\mathbf{G 2 1}$ was treated with a mixture of anhydrous $\mathrm{K}_{2} \mathrm{CO}_{3}$, tetra- $n$-butylammonium bromide (TBAB), and morpholine in acetonitrile to give $\mathbf{G}$. 


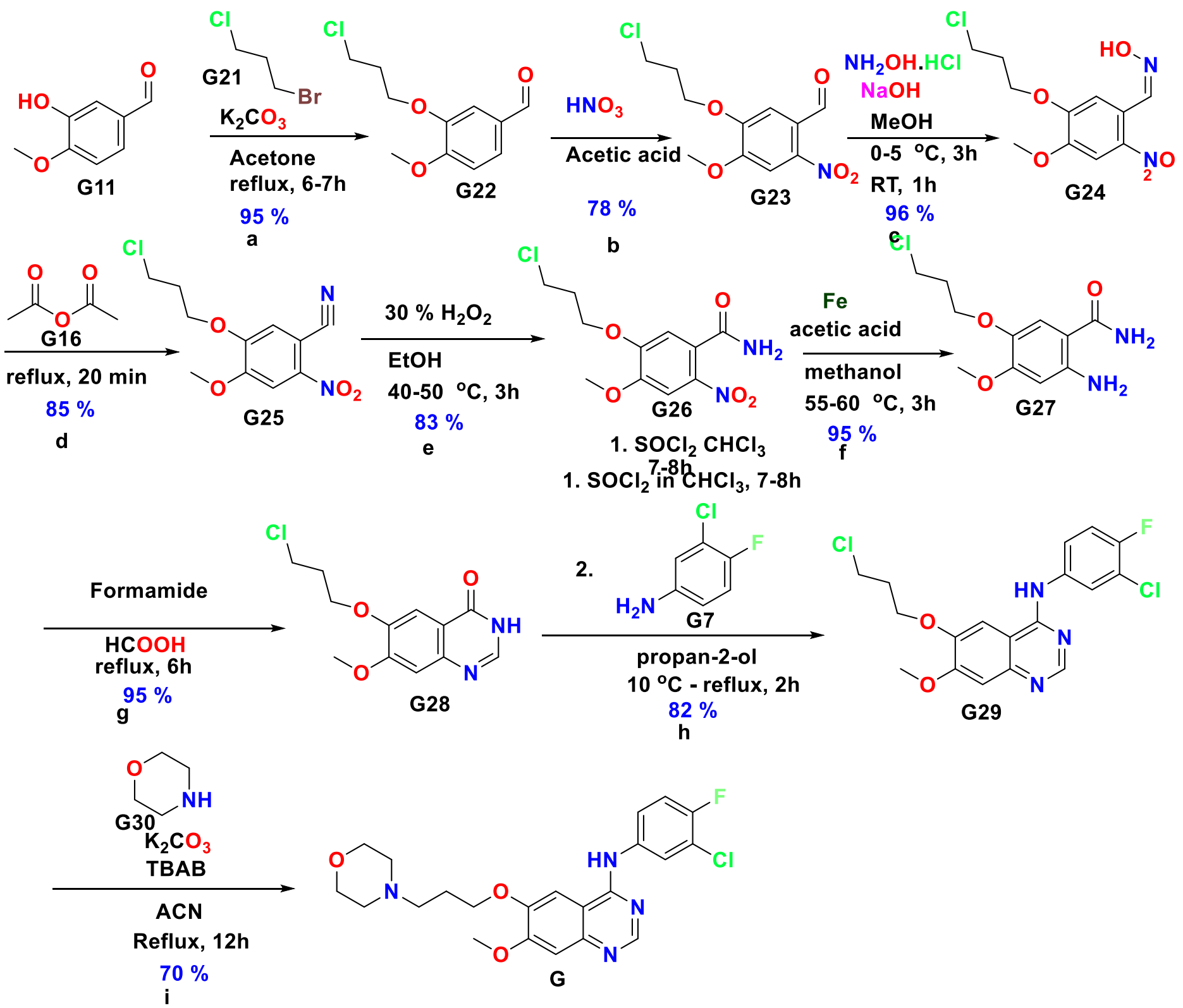

Reagents and conditions: a) 1-bromo-3-chloropropane $\mathbf{G 1 2}$ (1 mol. equiv.), $\mathrm{K}_{2} \mathrm{CO}_{3}$ (2 mol. equiv.), acetone, reflux, 6-7 h; b) $\mathrm{HNO}_{3}\left(70 \%, 4\right.$ mol. equiv.), acetic acid (4 vol.), RT, overnight; c) $\mathrm{NH}_{2} \mathrm{OH} . \mathrm{HCl}$ (2.2 mol. equiv.), $\mathrm{NaOH}$ (4.8 mol. equiv., 50\% aqueous solution), $\mathrm{MeOH}, 0-5{ }^{\circ} \mathrm{C}, 3 \mathrm{~h}, \mathrm{RT}, 1 \mathrm{~h}$; d) acetic anhydride $\mathrm{G} 16$ (305 mol. equiv.), reflux, 20 min.; e) $30 \% \mathrm{H}_{2} \mathrm{O}_{2}$ (2.7 mol. equiv.), EtOH, $40-50{ }^{\circ} \mathrm{C}, 3 \mathrm{~h}$ (caution: the temperature of reaction mixture should not rise above $50{ }^{\circ} \mathrm{C}$, otherwise explosion might occur due to the ignition of an oxygen-ethanol vapor mixture); f) Fe (1 mol. equiv.), acetic acid (3.6 vol.), methanol (2 vol.), 55-60 ${ }^{\circ} \mathrm{C}, 1.5 \mathrm{~h}$; g) Formamide (8.3 mol. equiv.), $\mathrm{HCOOH}$ (8.6 mol. equiv.), reflux, $6 \mathrm{~h}$; h) 1) $\mathrm{SOCl}_{2}$ (7 vol.), $\mathrm{CHCl}_{3}, 7-8 \mathrm{~h}$; 2) 4-chloro-3-fluoroaniline G7 (27 mol. equiv.), propan-2-ol, $10{ }^{\circ} \mathrm{C}$ to reflux, $2 \mathrm{~h}$; i) 4-(3- morpholine (80 mol. Equiv.), $\mathrm{K}_{2} \mathrm{CO}_{3}(0.7 \mathrm{~mol}$. equiv.), tetra-n-butylammonium bromide(TBAB) (0.06 mol. equiv.), ACN, reflux, $12 \mathrm{~h}$.

Scheme 6. Multigram scale synthesis of gefitinib (G).

\subsection{Erlotinib (Tarceva ${ }^{\circledR}$ - Roche Pharmaceuticals)}

Erlotinib (E) (Figure 5) is an inhibitor of the EGFR-TK that is used in the treatment of non-small cell lung cancer, pancreatic cancer and several other types of cancer. It is typically marketed under the trade name Tarceva. ${ }^{23}$ 
<smiles>C#Cc1cccc(Nc2ncnc3cc(OCCOC)c(OCCOC)cc23)c1</smiles>

Figure 5. Chemical structure of erlotinib (E).

4.3.1. Synthesis of Erlotinib (E). The initial synthesis of $\mathbf{E}$ was reported by Schnur et al. in 1998. The two hydroxyl groups on ethyl 3,4-dihydroxybenzoate E1 were alkylated with 1-bromo-2-methoxyethane E2 to afford potassium salt of 3,4-bis(2-methoxyethoxy)benzoate E3. E3 undergoes a nitration reaction in the presence of nitric acid to afford the corresponding nitro E4 which was reduced and esterified to afford E5. Cyclization of E5 yielded quinazolin-4(3H)-one E6. Chlorination followed by substitution with 3-ethynylaniline E8 afforded E (Scheme 7). ${ }^{24}$ In this approach, 4-chloro quinazoline E7 is a key intermediate and its synthesis involves the use of corrosive and toxic reagents such as oxalyl chloride, a highly flammable gas such as hydrogen at high pressure and costly reagents such as platinum oxide.

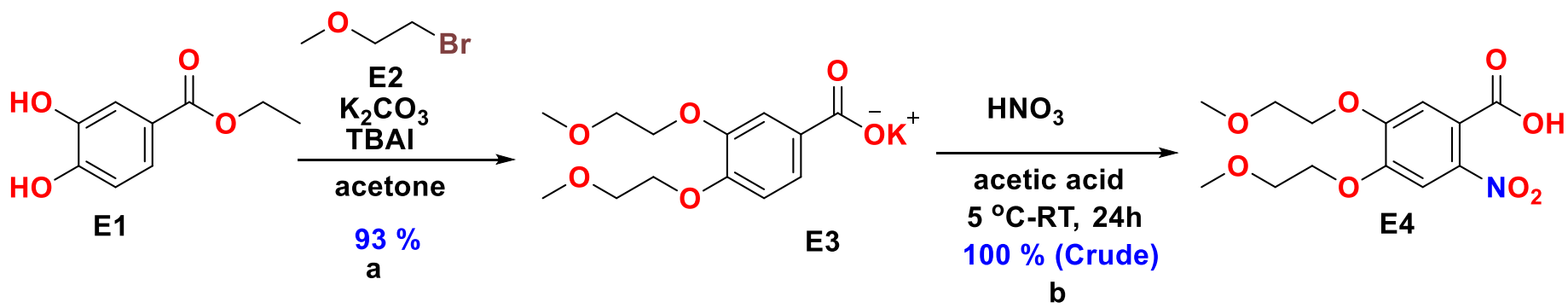

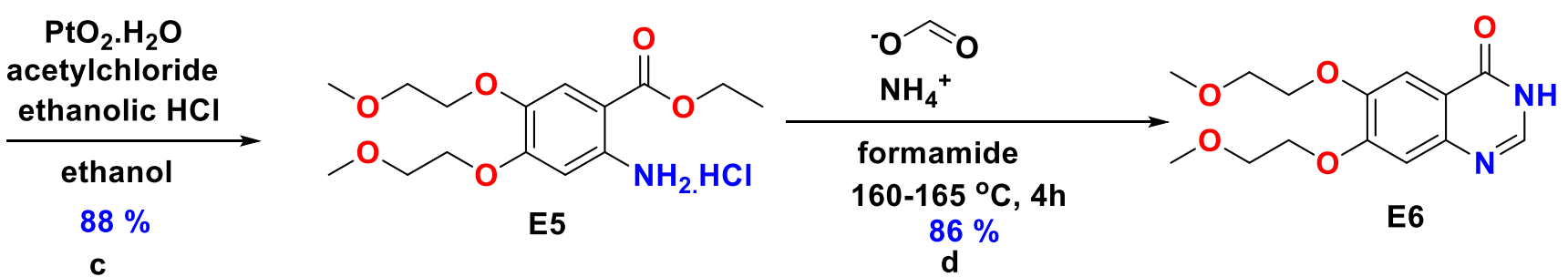

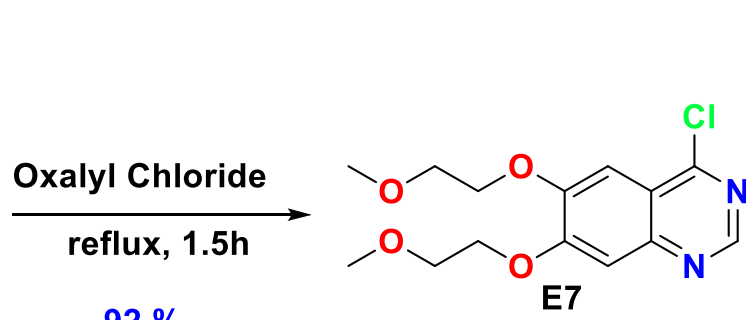

$92 \%$

e

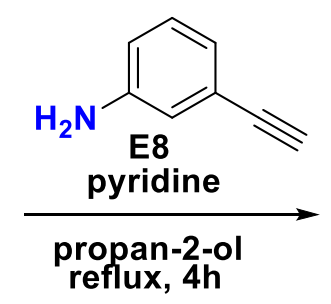

$1 \mathrm{M} \mathrm{HCl}$ in ether $71 \%$

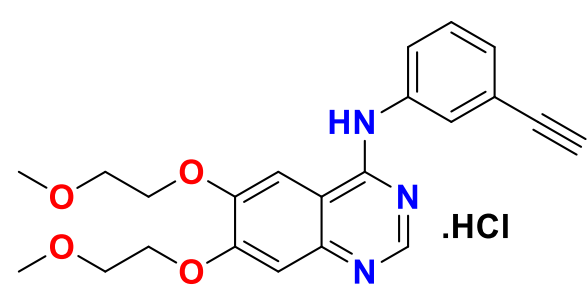

E

Reagents and conditions: a) 1-bromo-2-methoxyethane E2 (2.5 mol. equiv.), $\mathrm{K}_{2} \mathrm{CO}_{3}$ (2.2 mol. equiv.), tetrabutylammonium iodide TBAI (0.01 mol. equiv.), acetone, reflux, $64 \mathrm{~h}$; b) $\mathrm{HNO}_{3}(70 \%, 2.8$ mol. equiv.) , acetic acid (17 mol. equiv.), $5{ }^{\circ} \mathrm{C}-\mathrm{RT}, 24 \mathrm{~h}$; c) acetyl chloride (1 mol. equiv.), ethanolic $\mathrm{HCl}(1 \mathrm{~mol}$. equiv.), $\mathrm{PtO}_{2} . \mathrm{H}_{2} \mathrm{O}$ (0.03 mol. equiv.), $\mathrm{EtOH}, 45 \mathrm{psi} \mathrm{H2,6} \mathrm{h}, \mathrm{RT}$; d) Formamide (13.2 mol. equiv.), ammonium formate (1 mol. equiv.), $160-165^{\circ} \mathrm{C}, 3 \mathrm{~h}$; e) oxalyl chloride (3.3 mol. equiv.), reflux, $1.5 \mathrm{~h}$; f) 3-ethynylaniline E8 (1.1 mol. equiv.), pyridine (1.1 mol. equiv.), propan-2-ol, reflux, $4 \mathrm{~h}, 1 \mathrm{M} \mathrm{HCl}$ in ether.

Scheme 7. Initial synthesis of erlotinib (E). 
Considering these difficulties Ramanadham et al. developed a simple and economically viable process for the preparation of Erlotinib (E) (Scheme 8). ${ }^{25}$ The basic raw material selected for synthesis is 6,7dimethoxyquinazolin-4(3H)-one E9. E9 was reacted with aqueous $\mathrm{HBr}$ to synthesize dihydroxy E10. The acetylation of E10 with acetic anhydride and pyridine formed the corresponding bis-acylated derivative E11. The carbonyl group of E11 was converted in to leaving group ' $\mathrm{Cl}$ ' using oxalylchloride under reflux conditions to afford intermediate E12 which was condensed in situ after workup with 3-ethynylaniline E8 under reflux conditions to afford E13. E13 was de-acylated with aqueous ammonia to form E14 which was further reacted with 2-iodo-ethylmethylether E15 in the presence of base to synthesize E16 which was converted into Erlotinib hydrochloride by treatment with $\mathrm{HCl}$ in propan-2-ol.

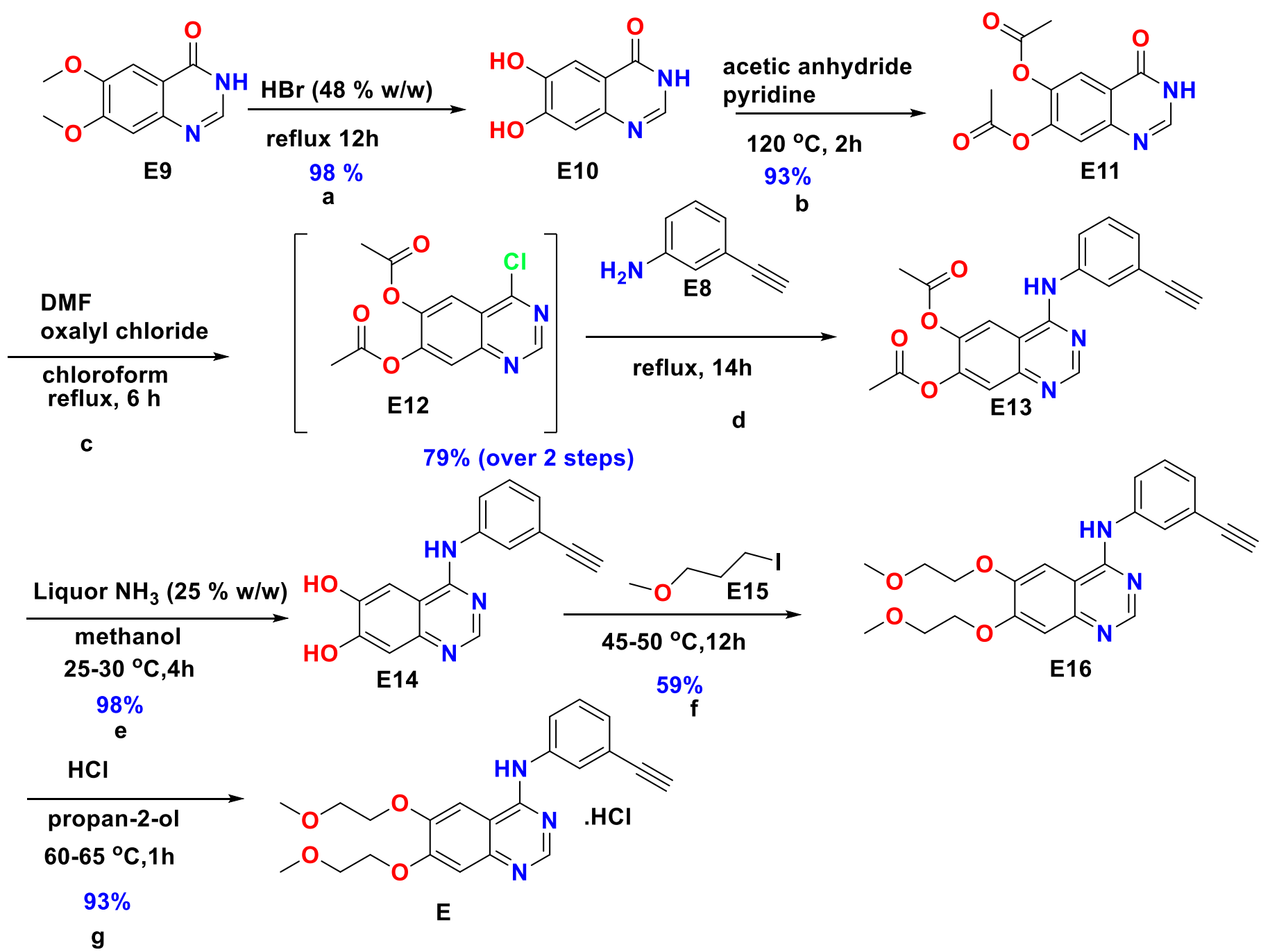

Reagents and conditions: a) $48 \%$ aqueous $\mathrm{HBr}\left(12.2\right.$ mol. equiv.), $110{ }^{\circ} \mathrm{C} 1 \mathrm{~h}$, reflux $12 \mathrm{~h}$; b) pyridine $(0.09$ mol. equiv.), acetic anhydride (10.5 mol. equiv.); $120{ }^{\circ} \mathrm{C}, 2 \mathrm{~h}$; c) DMF (0.14 mol. equiv.), oxalyl chloride-drop wise addition (2.1 mol. equiv.), reflux, $6 \mathrm{~h}$; d) 3-ethynylaniline E8 (1 mol. equiv.), reflux, $14 \mathrm{~h}$; e) Liquor ammonia (25\% w/w, 2.8 mol. equiv.), methanol, $25-30{ }^{\circ} \mathrm{C} 1 \mathrm{~h}$, reflux $4 \mathrm{~h}$; f) $\mathrm{K}_{2} \mathrm{CO}_{3}$ (6 mol. equiv.), 1-iodo-3methoxypropane E15 (2 mol. equiv.), DMF, $45-50{ }^{\circ} \mathrm{C} 12 \mathrm{~h}$; g) propan-2-ol-HCl (1.1 mol. equiv.), propan-2-ol, $60-65^{\circ} \mathrm{C} 1 \mathrm{~h}$.

Scheme 8. Synthesis of erlotinib (E). 
Chandregowda et al. reported simplified conditions for the synthesis of E (Scheme 9). ${ }^{26}$ Their approach involves a similar synthetic process for synthesis of E7 as depicted in Scheme 8. Treatment of E7 with 3ethynylaniline E8 in DMF without using extra base afforded erlotinib (E) as the hydrochloride salt.

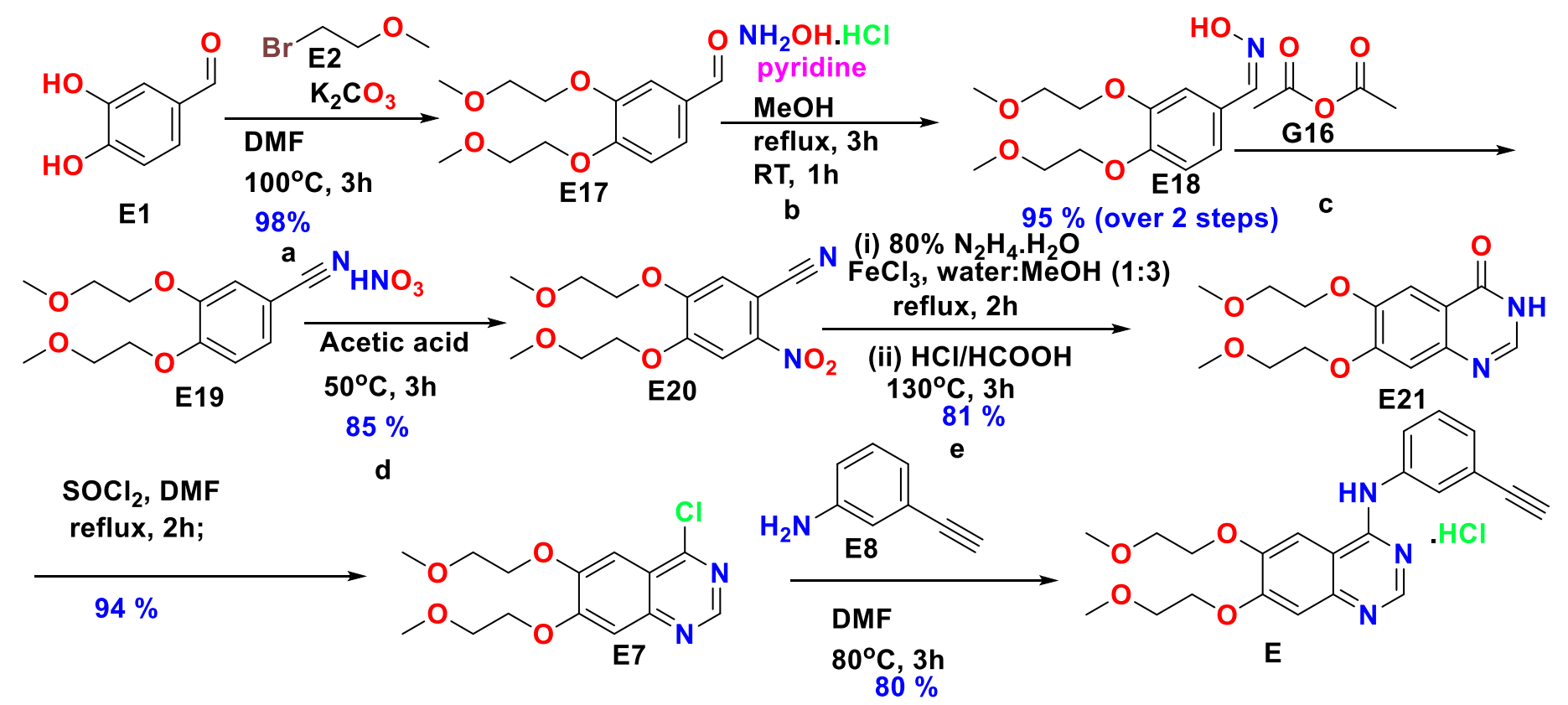

f (i)

f(ii)

Reagents and conditions: a) 1-bromo-2-methoxyethane E2 (1.1 mol. equiv.), $\mathrm{K}_{2} \mathrm{CO}_{3}$ (2 mol. equiv.), DMF, 100 ${ }^{\circ} \mathrm{C}, 3 \mathrm{~h}$; b) $\mathrm{NH}_{2} \mathrm{OH} . \mathrm{HCl}$ (2 mol. equiv.), pyridine (2 mol. equiv), $\mathrm{MeOH}$, reflux, $1 \mathrm{~h}$; c) acetic anhydride $\mathbf{G 1 6}$ (6.34 mol. equiv.), $110{ }^{\circ} \mathrm{C}, 3 \mathrm{~h}$.; d) $\mathrm{HNO}_{3}$ (70\%, 4 mol. equiv.), acetic acid (1.4 vol.), 45-50 ${ }^{\circ} \mathrm{C}, 8 \mathrm{~h}$; e) i) $\mathrm{FeCl}_{3}(0.006$ mol. equiv.), $80 \%$ hydrazine hydrate (4.7 mol. equiv.), water: $\mathrm{MeOH}(1: 3)$, reflux, $3 \mathrm{~h}$; ii) $35 \% \mathrm{HCl}(6 \mathrm{~mol}$. equiv.), formic acid ( 2.3 mol. equiv.), $130{ }^{\circ} \mathrm{C}, 3 \mathrm{~h}$; f) i) $\mathrm{SOCl}_{2}$ (24.3 mol. equiv.), DMF (0.42 mol. equiv.), reflux, 2 h; ii) 3-ethynylaniline E8 (1 mol. equiv.), DMF, $80^{\circ} \mathrm{C}, 1 \mathrm{~h}$.

Scheme 9. Industrial scale synthesis of erlotinib (E).

The synthesis of $\mathbf{E}$ has also been accomplished by starting from E20, which in turn was prepared in an efficient way as described in Scheme 9. Nitro reduction of E20 using sodium dithionite in aqueous medium gave E22. E22 was treated with DMF-DMA in toluene to obtain formamidine derivative E23, which was reacted with 3-ethynylaniline E8 through Dimroth rearrangement to give erlotinib (E) (Scheme 10). ${ }^{27}$ 


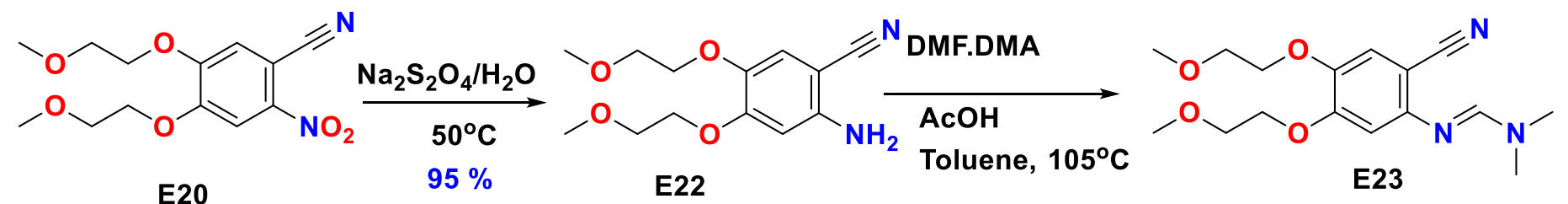

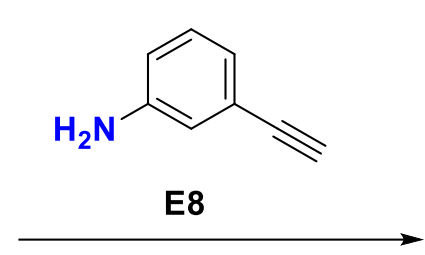

$\mathrm{AcOH}, 130^{\circ} \mathrm{C}$

C a

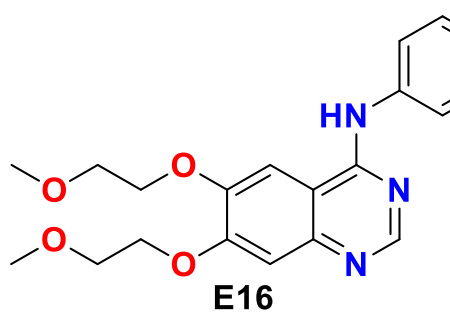

E16 b

$66 \%$ (over 2 steps)

Reagents and conditions: a) i) sodium dithionite (3.3 mol. Equiv.), water, $50{ }^{\circ} \mathrm{C}, 2.5 \mathrm{~h}$; ii) $25 \% \mathrm{HCl}(5 \mathrm{vol} . \mathrm{w} / \mathrm{w})$, $70{ }^{\circ} \mathrm{C}$, addition over a period $2.5 \mathrm{~h}$; b) i) DMF.DMA (2 mol. Equiv.), Acetic acid (0.06 mol. Equiv.), toluene, 105 ${ }^{\circ} \mathrm{C}$, dean-stark apparatus, $3 \mathrm{~h}$; ii) acetic acid (0.03 mol. equiv.), 3-ethynylaniline E8 (1 mol. Equiv. ), 125-130 ${ }^{\circ} \mathrm{C}$, $1 \mathrm{~h} ; \mathrm{c}) \mathrm{HCl}$ gas for $0.5 \mathrm{~h}$, methanol, $15-20^{\circ} \mathrm{C}$

Scheme 10. Improved industrial scale synthesis of erlotinib (E).

\subsection{Dacomitinib (Vizimpro ${ }^{\circledR}$ - Pfizer Inc.)}

Dacomitinib (D) (Figure 6) is a second-generation tyrosine kinase inhibitor and used for the treatment of nonsmall-cell lung carcinoma (NSCLC). It is characterized by the irreversible binding at the ATP domain of the epidermal growth factor receptor family kinase domains. Dacomitinib was developed by Pfizer Inc. and approved by the US FDA in 2018. ${ }^{28}$

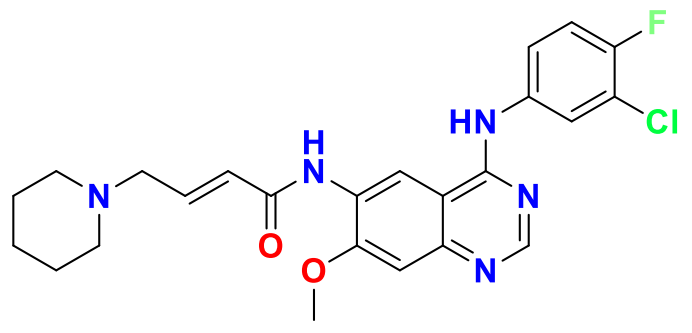

Figure 6. Chemical structure of dacomitinib (D).

4.4.1. Synthesis of dacomitinib (D). The synthesis of this is mainly divided into two parts viz. synthesis of the quinazoline and synthesis of the crotonate. In the lab scale synthesis, ${ }^{29-31}$ the quinazoline moiety was synthesized from 2-amino-4-fluorobenzoic acid D1 (Scheme 11). D1 was cyclized with formamidine D2 to form 7-fluoroquinazolin-4(3H)-one D3 which undergoes nitration to get D4, Chlorination to form intermediate D5, amination with $\mathbf{G 7}$ to afford D6 followed by $\mathrm{O}$-methylation afforded D7. Reduction of the nitro group in D7 to amine in presence of Raney $\mathrm{Ni}$ afforded the desired quinazoline D8. Synthesis of (E)-4-bromobut-2-enoyl chloride D11 was done by hydrolysis of methyl (E)-4-bromobut-2-enoate D9 to form the corresponding acid D10 which was followed by acyl chloride formation. This intermediate was used to couple with quinazoline D8 to form the corresponding amide D12. D12 was reacted with piperidine D13 to afford D. The disadvantage of 
this approach is that the cost is high, column purification is needed in 2-3 steps and overall yield is low especially for last step in which substitution with pyridine was needed to produce $\mathbf{D}$.<smiles>Nc1cc(F)ccc1C(=O)O</smiles><smiles>O=[N+]([O-])c1cc2c(Cl)ncnc2cc1F</smiles>

91\% (over 2 steps)

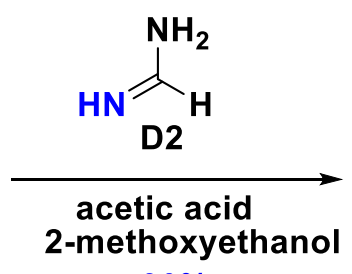

$90 \%$<smiles>CC(c1cc(Cl)c(F)cc1N)C(C)(F)F</smiles>

$\mathrm{RT}, 1.5 \mathrm{~h}$ propan-2-ol

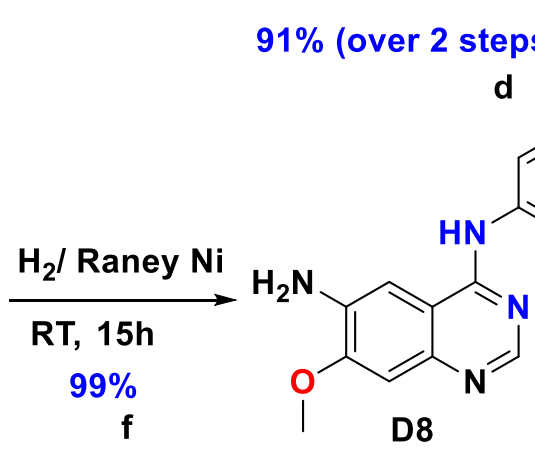

f<smiles>O=c1[nH]cnc2cc(F)ccc12</smiles>

D3

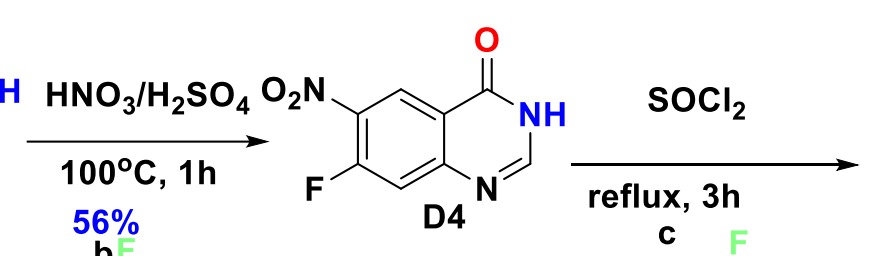<smiles>C=C(/C=C/P)Nc1ncnc2cc(Br)c([N+](=O)[O-])cc12</smiles>

$6 \%$

$\underset{c}{\text { reflux, }}$ 3h<smiles>CC(C)C(=O)O[Na]</smiles>

\section{$65^{\circ} \mathrm{C}, 26 \mathrm{~h}$}

$91 \%$

D7<smiles>COc1cc2ncnc(Nc3ccc(Cl)c(F)c3)c2cc1[N+](=O)[O-]</smiles><smiles>C=C(F)CCl</smiles><smiles>O=C(Cl)CCCCCCC(=O)Cl</smiles>

$\mathbf{h}$

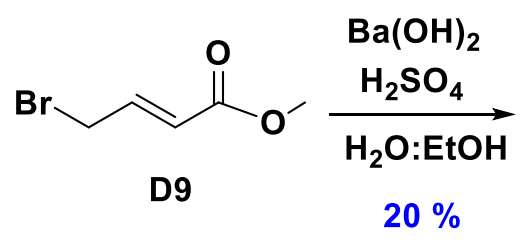<smiles>O=C(O)/C=C/CBr</smiles><smiles>O=C(Cl)/C=C/CBr</smiles>

Reagents and conditions: a) formamidine D2 (2 mol. equiv.), 2-methoxy ethanol, reflux, $18 \mathrm{~h}$; b) fuming $\mathrm{HNO}_{3}$ (8.2 mol. equiv.), $100{ }^{\circ} \mathrm{C}, 1 \mathrm{~h}$; c) $\mathrm{SOCl}_{2}$ (55.2 mol. equiv.), reflux, $3 \mathrm{~h}$; d) 4-chloro-3-fluoroaniline G7 (1 mol. equiv.), TEA ( 1 mol. equiv.), propan-2-ol, RT, $1.5 \mathrm{~h}$; e) $\mathrm{NaH}$ (60\% in mineral oil, 1.5 mol. equiv.), methanol (1.5 mol. equiv.), THF, $26 \mathrm{~h}, 65^{\circ} \mathrm{C}$; f) Raney $\mathrm{Ni}(0.6 \mathrm{w} / \mathrm{w})$, hydrogen balloon, $15 \mathrm{~h}, \mathrm{RT}$; g) $\mathrm{Ba}(\mathrm{OH})_{2}(0.5$ mol. equiv.), $\mathrm{H}_{2} \mathrm{SO}_{4}$ (0.5 mol. equiv.), water:EtOH (1:0.34), $-11^{\circ} \mathrm{C}$ to $\mathrm{RT}, 16 \mathrm{~h}$; h) i) oxalyl chloride (0.45 mol. equiv.), DMF (34 drops), DCM, RT, $1.5 \mathrm{~h}$; ii) (E)-4-bromobut-2-enoyl chloride D11(crude), N4-(4-chloro-3-fluorophenyl)-7methoxyquinazoline-4,6-diamine D8 ( 1.6 mol. equiv.), TEA (1.5 mol. equiv.), $0{ }^{\circ} \mathrm{C}, 1 \mathrm{~h}$; j) piperidine D13 (1 mol. equiv.), TEA ( 3 mol. equiv.), DMA, $0{ }^{\circ} \mathrm{C}, 17 \mathrm{~h}$.

Scheme 11. Lab scale synthesis of dacomitinib (D).

This last approach was further improved by slight modification in some of the reaction conditions and alterations in reaction sequences. ${ }^{32} \mathrm{Yu}$ et al. developed $\mathrm{N}$-arylation route (Scheme 12 ) in which easily available 2-amino-4-methoxybenzoic acid D14 was used as starting material. lodination of D14 using $N$-lodosuccinimide 
afforded D15 in excellent yield and regioselectivity. ${ }^{33}$ Condensation of D15 with amidine acetate D2 yielded intermediate D16, which was crystallized from the reaction mixture to afford a pure compound.

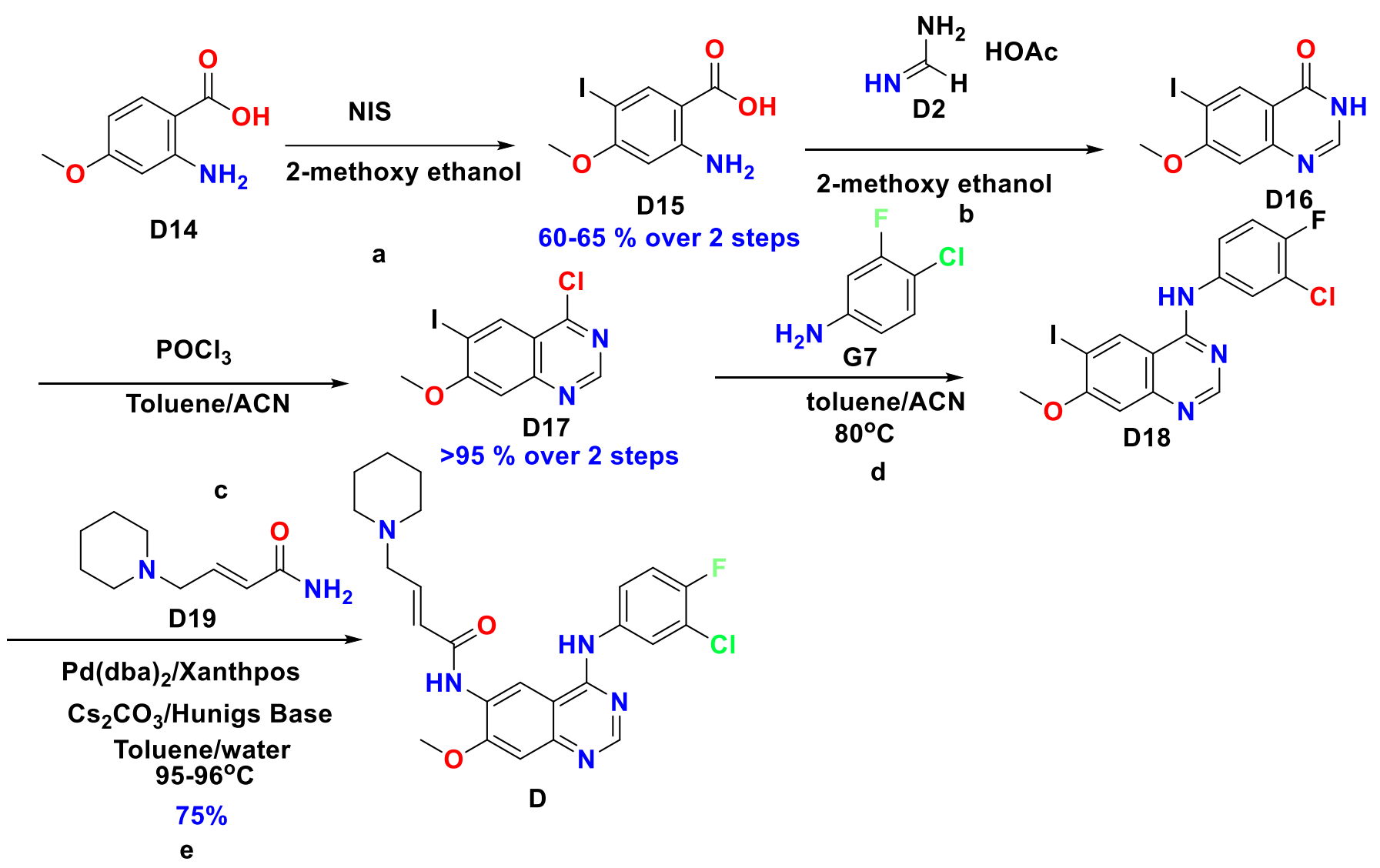

Reagents and conditions: a) 2-amino-4-methoxybenzoic acid D14, NIS, 2-methoxy ethanol; b) formimidamide acetate, 2-methoxy ethanol, reflux, overnight; c) $\mathrm{POCl}_{3}$, toluene/acetonitrile, reflux; d) 4-chloro-3-fluoroaniline G7 (1 mol. equiv.), toluene/acetonitrile, $80{ }^{\circ} \mathrm{C}, 3 \mathrm{~h}$; e) (E)-4-(piperidin-1-yl)but-2-enamide D16, $\mathrm{Pd}(\mathrm{dba})_{2} /$ Xanthpos, $\mathrm{Cs}_{2} \mathrm{CO}_{3} /$ Hunigs Base, Toluene/water, $95-96^{\circ} \mathrm{C}$.

Scheme 12. N-arylation route to dacomitinib (D).

The chlorination of D16 was conducted in a mixture of toluene and acetonitrile. This mixture of solvents also served well during the nucleophilic aromatic substitution to afford D18. Therefore, D18 was produced through telescoped process from D16 via D17 over two steps. Palladium catalyzed $\mathrm{N}$-arylation with D19 was done at this stage to form $\mathbf{D}$. The initial synthesis route was significantly improved to enable the delivery of kilo scale synthesis by changing reagents, solvents and conditions in due course. The medicinal chemistry route was changed in order to meet the API demand for pre-clinical and clinical studies. An efficient three-step process was developed to manufacture dacomitinib (D) on a commercial scale by utilizing the Dimroth Rearrangement for cyclization. ${ }^{34}$ The nitro group reduction of D20 was performed with Pd/C carbon catalysts using acetonitrile as solvent to enable telescoping with the next step to afford D21.

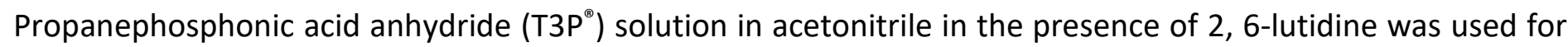
the coupling reaction to afford D23 without isolation of intermediate D21. A Dimroth reaction in acetic acid in acetonitrile at $30^{\circ} \mathrm{C}$ afforded $\mathbf{D}$ (Scheme 13$)$. 


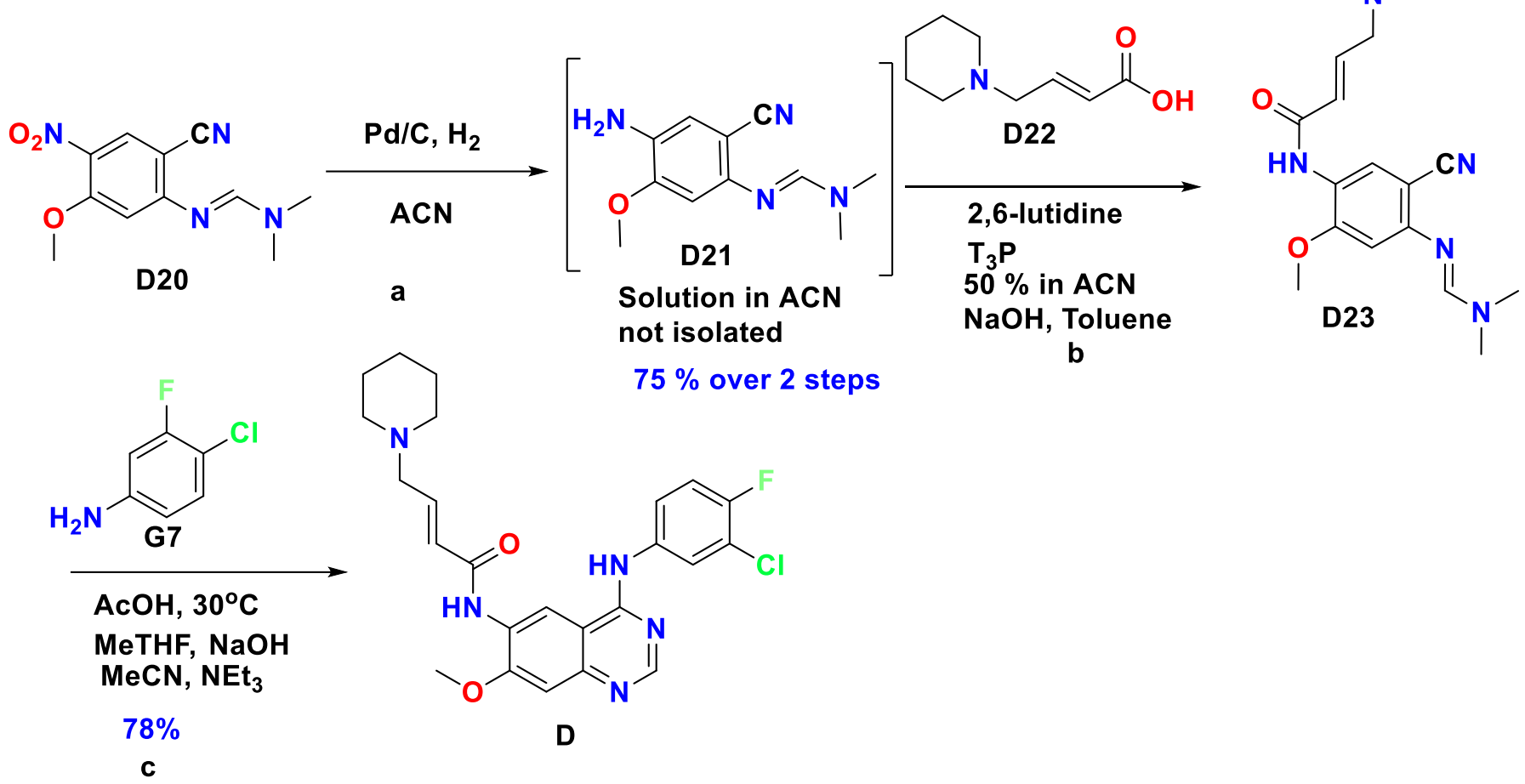

Reagents and conditions: a) Pd/C, hydrogen gas, $\mathrm{ACN}, 3 \mathrm{~h}$; b) 2,6-lutidine, propanephosphonic acid anhydride $\mathrm{T}_{3} \mathrm{P}, 50 \%$ in acetonitrile:toluene, $\mathrm{RT}$; c) 4-chloro-3-fluoroaniline $\mathrm{G7}, \mathrm{AcOH}, \mathrm{Me}-\mathrm{THF}$, acetonitrile, $30{ }^{\circ} \mathrm{C}, 16 \mathrm{~h}$.

Scheme 13. Commercial process to dacomitinib (D).

\subsection{Lapatinib (Tykerb ${ }^{\circledR}$ and Tyverb $^{\circledR}$ - GlaxoSmithKline (GSK))}

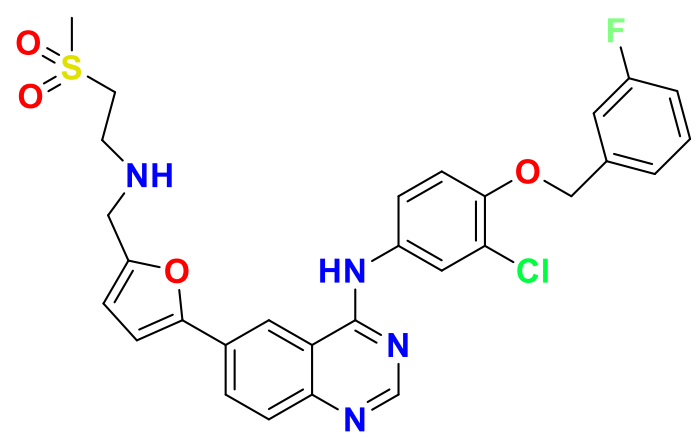

Figure 7. Chemical structure of lapatinib (L).

Lapatinib (L) (Figure 7) is an anti-cancer drug developed by GlaxoSmithKline (GSK) as a treatment for solid tumours such as breast and lung cancer. It was approved by the US FDA, in 2007, for use in patients with advanced metastatic breast cancer in conjunction with the chemotherapy drug Capecitabine. ${ }^{35}$

4.5.1. Synthesis of Lapatinib (L). The first reported synthesis of lapatinib (L) was conducted using three convergent steps (Scheme 14). ${ }^{36}$ The hydroxyl group of commercially available 2-chloro-4-nitrophenol L1 was reacted with 1-(bromomethyl)-3-fluorobenzene $\mathbf{L} 2$ to afford 2-chloro-1-((3-fluorobenzyl)oxy)-4-nitrobenzene L3 which was reduced to corresponding amine L4. L4 was reacted with 4-chloro-6-iodoquinazoline $\mathbf{L} 5$ to afford L6. Suzuki-Miyaura (S-M) coupling of L6 with (5-formylfuran-2-yl)boronic acid L7 afforded intermediate 
L8. Reductive amination of L8 with 2-(methylsulfonyl)ethan-1-amine L9 (synthesized by method $\mathbf{1}$ or method $\mathbf{2}$ as shown in scheme 13) afforded lapatinib L. This approach was good for synthesis on a milligram scale but optimization work was necessary to improve the yield and reproducibility of the reactions specifically for the S-M coupling reaction to afford $\mathbf{L} 8$ in sufficient scale.
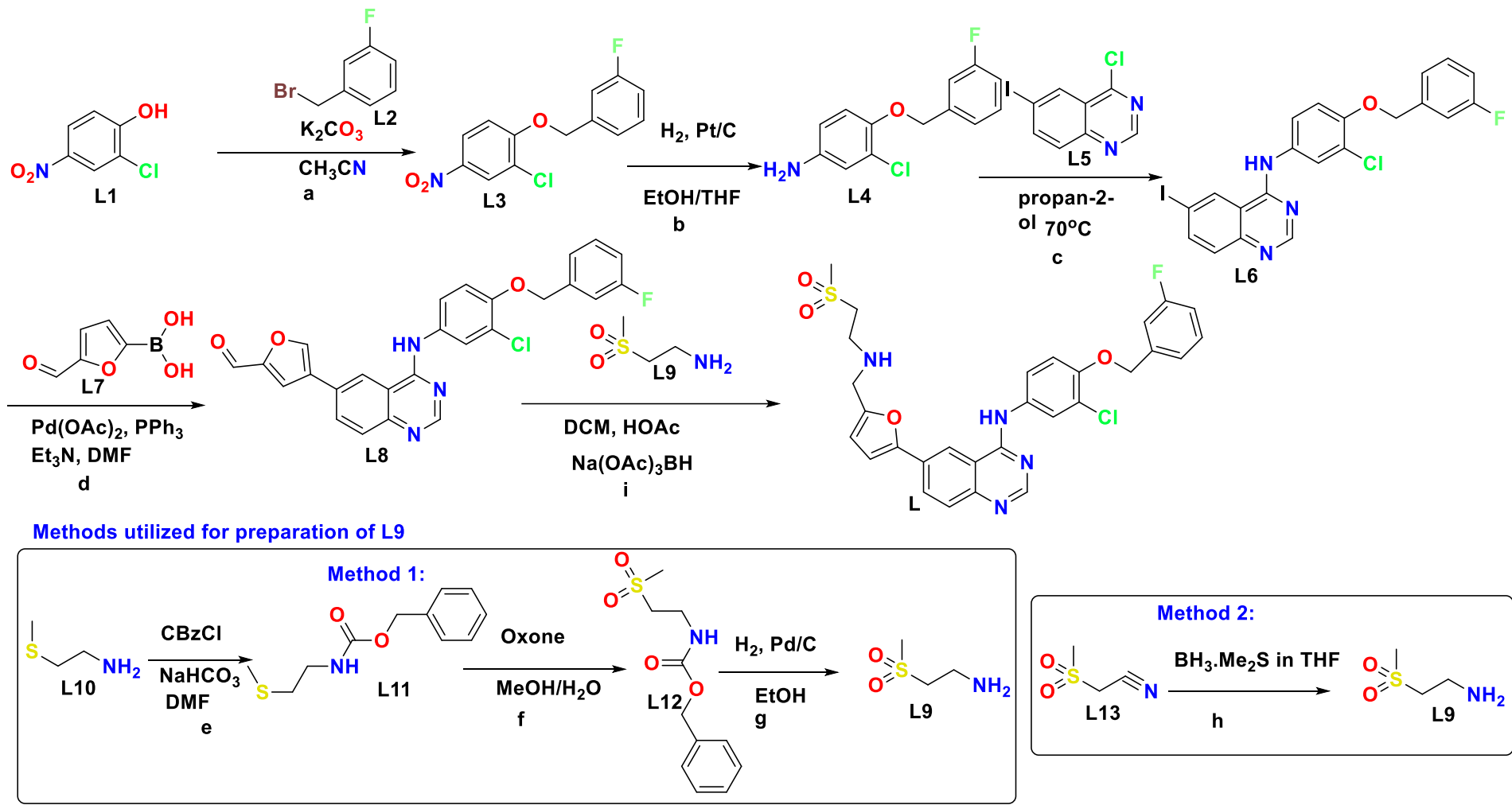

Reagents and conditions: a) 1-(bromomethyl)-3-fluorobenzene $\mathbf{L 2}, \mathrm{K}_{2} \mathrm{CO}_{3}$, acetonitrile; b) Pd/C, hydrogen gas, $\mathrm{EtOH} / \mathrm{THF}$; c) 4-chloro-6-iodoquinazoline L5, propan-2-ol, $70{ }^{\circ} \mathrm{C}$; d) (5-formylfuran-2-yl)boronic acid L7, $\mathrm{Pd}(\mathrm{OAC})_{2}, \mathrm{PPh}_{3}$, triethylamine, DMF; e) 2-(methylthio)ethan-1-amine L10, benzyl carbonochloridate $\mathrm{CBzCl}$, $\mathrm{NaHCO}_{3}, \mathrm{DMF}$; f) Oxone, $\left.\mathrm{MeOH} / \mathrm{H}_{2} \mathrm{O} ; \mathrm{g}\right) \mathrm{Pd} / \mathrm{C}$, hydrogen gas, EtOH; h) 2-(methylsulfonyl)acetonitrile L13, $\mathrm{BH}_{3} . \mathrm{Me}_{2} \mathrm{~S}$ in THF, THF; i) 2-(methylsulfonyl)ethan-1-amine $\mathbf{L}$ 9, sodium triacetoxyborohydride $\mathrm{Na}(\mathrm{OAC})_{3} \mathrm{BH}$, acetic acid, DCM.

Scheme 14. Synthesis of lapatinib (L).

A new pathway for the synthesis of this was reported in which the hydroxyl group of 6iodoquinazoline-4-ol is protected by the tetrahydropyranyl group hence entailing greater solubility of the intermediates in common organic solvents the lack of which was a major disadvantage of the process discussed above. ${ }^{37}$ Keeping in mind the difficulties for the preparation of Lapatinib $\mathbf{L}$ on a commercial scale, Prasad et al. developed a simple, economically viable and commercially applicable process for the preparation of lapatinib L. ${ }^{32}$ This process involved the reaction of 3-chloro-4-(3-fluorobenzyloxy)-aniline L4 with N, Ndimethylformamide dimethylacetal L14 carried out in the presence of acetic acid to afford L15. Reaction of 2aminobenzonitrile $\mathbf{L} 16$ with iodinemonochloride $\mathbf{I C I}$ in acetic acid yielded $\mathbf{L 1 7}$ which underwent Dimorth Rearrangement with L15 in acetic acid to afford L18. S-M coupling of L18 with (5-formylfuran-2-yl)boronic acid $\mathbf{L 7}$ afforded the corresponding aldehyde $\mathbf{L} 19$. Imination followed by reduction of $\mathbf{L} 19$ yielded lapatinib $\mathbf{L}$ which was converted to its pharmaceutically acceptable ditosylate monohydrate salt L.TSOH (Scheme 15). 


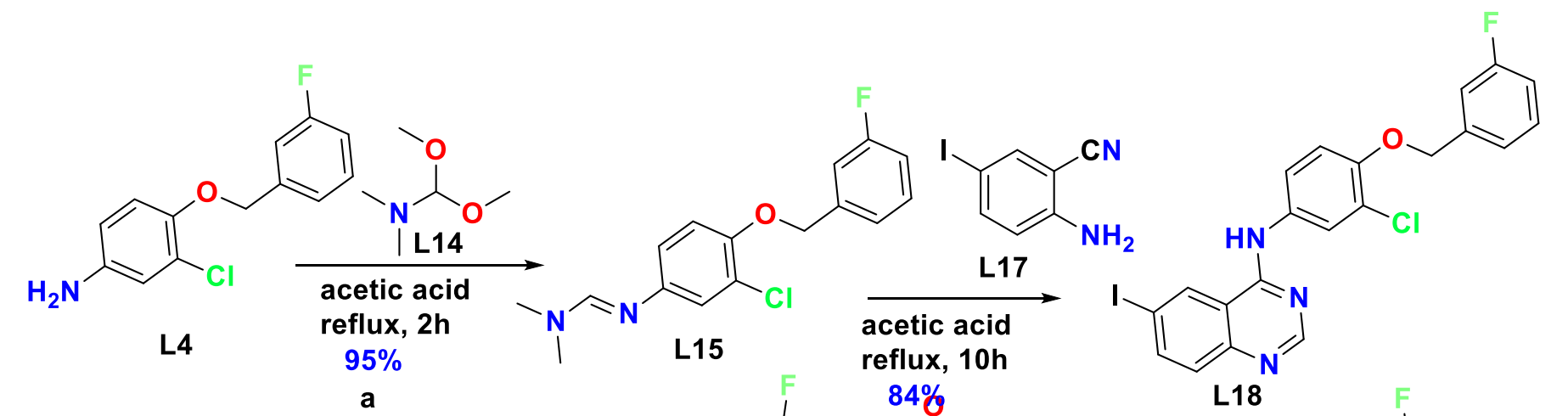<smiles>O=Cc1ccc(B(O)O)o1</smiles>

a

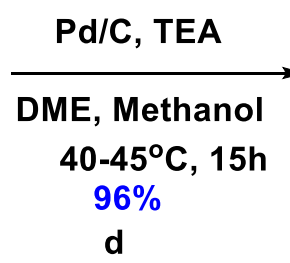<smiles>C=C(C)Nc1ncnc2ccc(-c3ccc(C=O)o3)cc12</smiles>
L19<smiles>COc1ccc(Nc2ncnc3ccc(-c4ccc(CNCCS(C)(=O)=O)o4)cc23)cc1Cl</smiles>
f $\mathrm{L}$

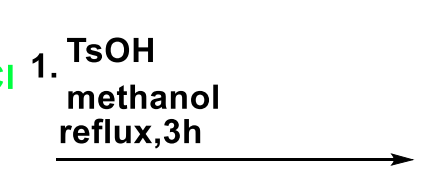

2.70\% propan-2-ol:water 75-80 ${ }^{\circ} \mathrm{C}, 20-30 \mathrm{~min}$. $80 \%$<smiles>Cc1ccc(S(=O)(=O)O)cc1</smiles>

L.TsOH

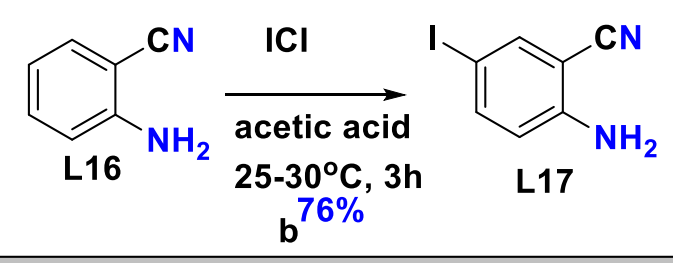

Reagents and conditions: a) 3,4-dihydro-2H-pyran L14 (8.6 mol. equiv.), TFA (0.1 mol. equiv.), toluene, 110$115{ }^{\circ} \mathrm{C}, 2-3 \mathrm{~h}$; b) (5-formylfuran-2-yl)boronic acid $\mathbf{L 7}$ (1.3 mol. equiv.), $\mathrm{Pd}_{2}(\mathrm{dba})_{3}$ (0.013 mol. equiv.), triphenylarsine (0.025 mol. equiv.), $\mathrm{K}_{2} \mathrm{CO}_{3}$ ( 2 mol. equiv.), DMF, 60-65 ${ }^{\circ} \mathrm{C}, 2 \mathrm{~h}$; c) 2-(methylsulfonyl)ethan-1amine. $\mathrm{HCl}$ L9 (1.5 mol. equiv.), DIPEA (1.5 mol. equiv.), sodium triacetoxyborohydride (2 mol. equiv.), DCM, 20-25 ${ }^{\circ} \mathrm{C}, 2 \mathrm{~h}$; d) $p$-toluenesulfonic acid $\mathrm{TsOH}$ (1.3 mol. equiv.), $\mathrm{MeOH}, 25{ }^{\circ} \mathrm{C}, 1 \mathrm{~h}$; e) $\mathrm{POCl}_{3}$ (1.2 mol. equiv.), TEA (1.2 mol. equiv.), toluene, $75^{\circ} \mathrm{C}, 3 \mathrm{~h}$; f) 3-chloro-4-((3-fluorobenzyl)oxy)aniline L4 (1 mol. equiv.), propan2-ol, $70{ }^{\circ} \mathrm{C}, 4 \mathrm{~h}$; g) $\mathrm{NaOH}\left(30 \%\right.$ aqueous solution, 5.1 mol. equiv.) TsOH (2.25 mol. equiv.), $40{ }^{\circ} \mathrm{C}, 3-4 \mathrm{~h}$; water (10 vol.), RT, $36 \mathrm{~h}$.

Scheme 15. Commercial process to lapatinib (L). 


\subsection{Vandetanib (Caprelsa ${ }^{\circledR}$ - AstraZeneca)}

Vandetanib (V) (Figure 8) is a kinase inhibitor of tumor angiogenesis and cell proliferation with the potential for use in a broad range of tumor types. Vandetanib was approved in 2011 by the US FDA to treat unresectable, locally advanced, or metastatic medullary thyroid cancer in adult patients. ${ }^{38}$

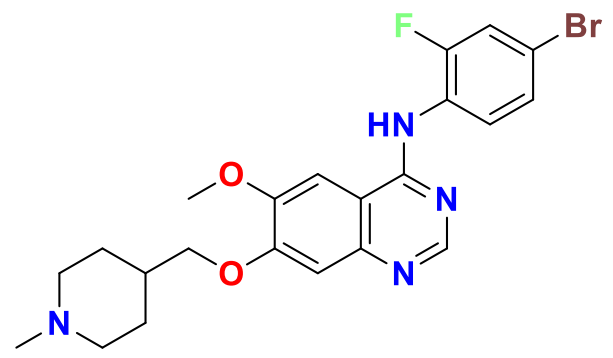

Figure 8. Chemical structure of vandetanib (V).

4.6.1. Synthesis of vandetanib (V). The initial literature precedence for the synthesis of vandetib (V) was reported via quinazolinone intermediate $\mathbf{6} 6$ starting from 3,4-dihydroxybenzoate $\mathbf{V 1}$. $^{39-43}$ The hyydroxyl group of V1 was protected using benzyl chloride $\mathbf{V} \mathbf{2}$ to afford intermediate V3 which was nitrated using conc. nitric acid in acetic acid to form V4. V4 was reduced to get methyl 2-amino-4-(benzyloxy)-5-methoxybenzoate V5 which was cyclized to afford quinazolinone intermediate V6. Chlorination of V6 yielded intermediate V7 which was substituted with 4-bromo-2-fluoroaniline $\mathbf{V 8}$ to afford V9. The benzyl group of V9 was de-protected and the hydroxyl group of compound V10 was substituted with boc-protected piperidine methyl group using tert-butyl 4-((tosyloxy)methyl) piperidine-1-carboxylate V14 to afford intermediate V15. Boc deprotection followed by methylation of $\mathbf{V 1 5}$ yielded vandetib V (Scheme 16). In another routes, quinazolin-4(3H)-one was protected with pivaloyloxymethyl chloride (POM-Cl) to afford $\mathrm{N}$-3-POM-protected quinazoline. Subsequent course of reactions was conducted to afford V. ${ }^{44}$ The synthetic strategies described above however are timeconsuming and involve harsh reaction conditions. Brocklesby et al reported an alternative synthesis of $\mathbf{V}$ via a Dimroth rearrangement avoiding quinazolinone. ${ }^{45}$
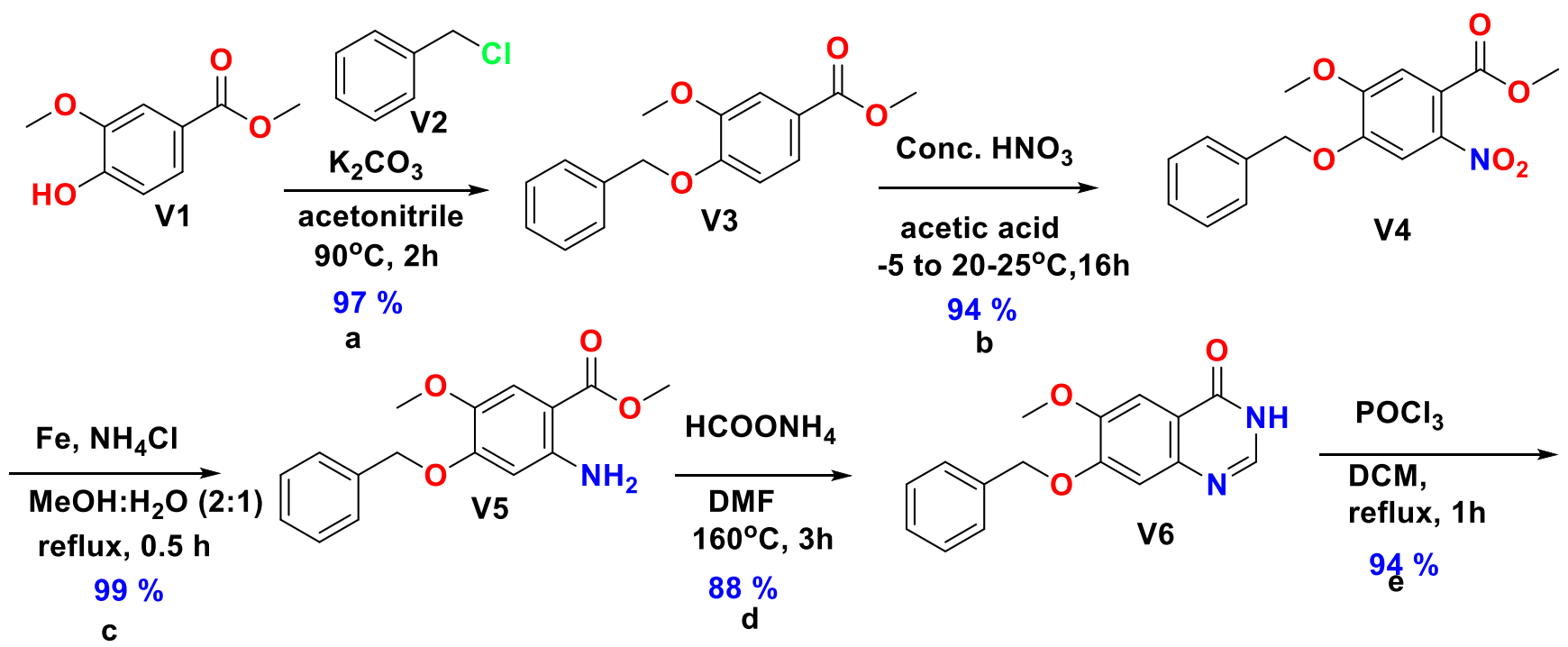

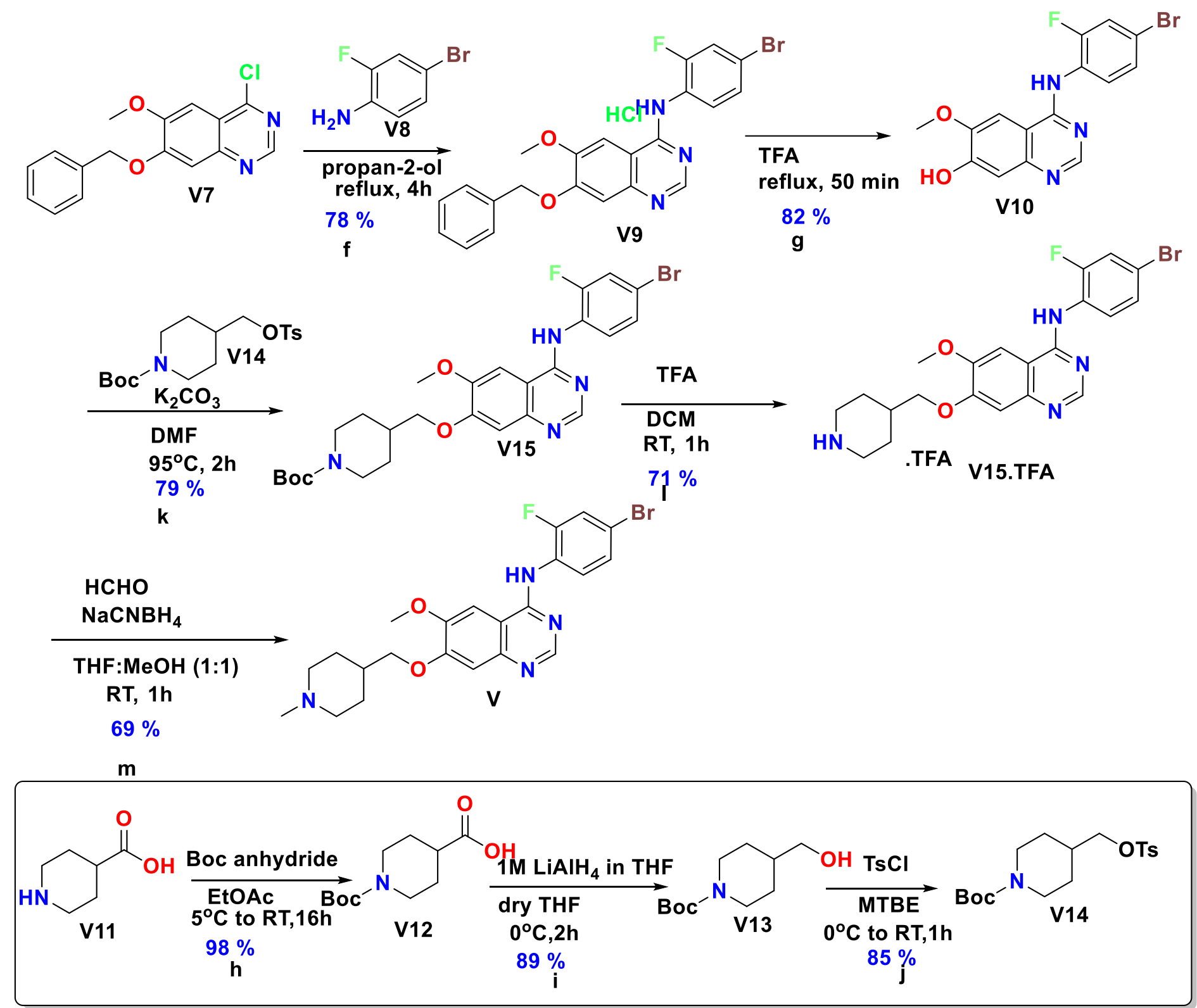

Reagents and conditions: a) (chloromethyl)benzene V2 (1 mol. equiv.), potassium carbonate ( 2.5 mol. equiv.), acetonitrile, $90{ }^{\circ} \mathrm{C}, 2 \mathrm{~h}$; b) Conc. $\mathrm{HNO}_{3}\left(24.7 \mathrm{~mol}\right.$. equiv.), acetic acid -5 to $20-25{ }^{\circ} \mathrm{C}, 16 \mathrm{~h}$; c) iron Fe $(18.5 \mathrm{~mol}$. equiv.), ammonium chloride (9.2 mol. equiv.), $\mathrm{MeOH}: \mathrm{H}_{2} \mathrm{O}$ (2:1), reflux, $0.5 \mathrm{~h}$; d) $\mathrm{POCl}_{3}$ (8 mol. equiv.), DCM, reflux, $1 \mathrm{~h}$; e) 4-bromo-2-fluoroaniline $\mathbf{V 8}$ (1.1 mol. equiv.), propan-2-ol, reflux, $4 \mathrm{~h}$; g) TFA (5.1 mol. equiv.), reflux, $50 \mathrm{~min}$; h) Boc anhydride (1 mol. equiv.), ethyl acetate, $5{ }^{\circ} \mathrm{C}$ to $\mathrm{RT}, 16 \mathrm{~h}$; i) $1 \mathrm{M} \mathrm{LiAlH} 4$ in THF (0.7 mol. equiv.), dry THF, $0{ }^{\circ} \mathrm{C}, 2 \mathrm{~h}$; j) DBU (1.5 mol. equiv.), toluene sulfonyl chloride $\mathrm{TsCl}$ (1.4 mol. equiv.), MTBE, $0{ }^{\circ} \mathrm{C}$ to RT,1h; k) tert-butyl 4-((tosyloxy)methyl)piperidine-1-carboxylate V14 (1.14 mol. equiv.), potassium carbonate (2 mol. equiv.), DMF, $95{ }^{\circ} \mathrm{C}, 2 \mathrm{~h}$; l) TFA (33.3 mol. equiv.), DCM, RT, $1 \mathrm{~h} ; \mathrm{m}$ ) $37 \%$ aqueous formaldehyde ( 2 mol. equiv.), sodium cyanoborohydride (1.2 mol. equiv.), THF:MeOH (1:1), RT, $1 \mathrm{~h}$.

Scheme 16. Initial synthesis of vandetib (V).

The synthesis started from the inexpensive building block 4-hydroxy-3-methoxybenzonitrile V16 (Scheme 17), which was alkylated with benzyl bromide V17 to form intermediate V18. Nitration of V18 under 
mild conditions afforded V19 in good yield. Selective reduction was done using sodium dithionite to afford V20. Compound V20 was reacted with large excess of DMF-DMA to aid solubility and formation of the formamidine V21. Microwave irradiation for 30 minutes at $90{ }^{\circ} \mathrm{C}$ afforded V21 in $95 \%$ yield while conventional heating at the same temperature provided $\mathbf{V} 21$ in a reduced yield of 58\% despite extending the reaction time to 120 minutes. TFA-mediated debenzylation of V21 yielded V22. Alkylation of V22 using tert-butyl4(tosyloxy)methyl)piperidine-1-carboxylate V14, which was synthesized by the method afforded V23. The key Dimroth rearrangement step was conducted in the presence of 4-bromo-3-fluoroaniline $\mathbf{V} \mathbf{8}$ and acetic acid with microwave heating at $130{ }^{\circ} \mathrm{C}$ for 45 minutes to afford V15. The penultimate step in the synthesis of $\mathbf{V}$ was the Boc deprotection of piperidine, which was done as per above procedure.

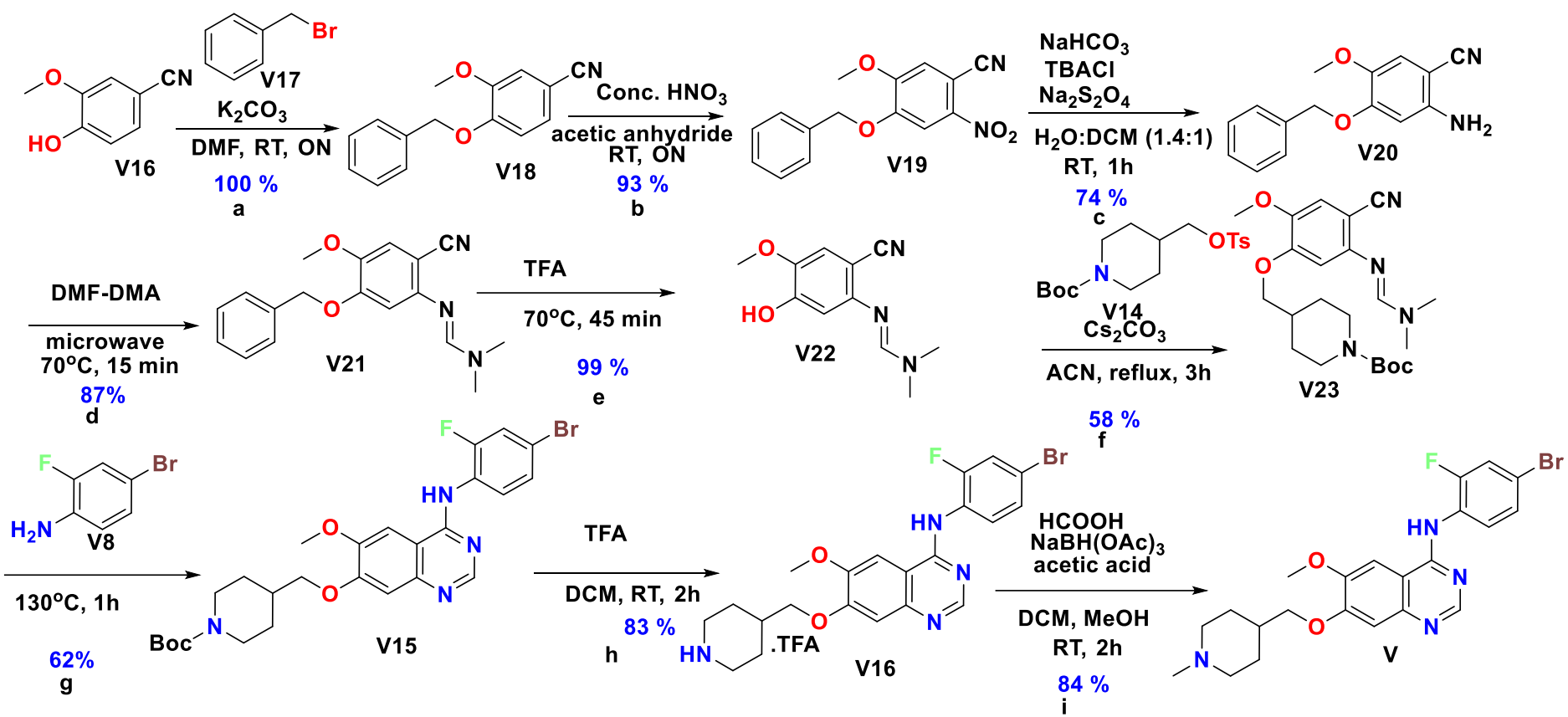

Reagents and conditions: a) (bromomethyl) benzene V26 (1.1 mol. equiv.), potassium carbonate (2.5 mol. equiv.), DMF, RT, ON; b) Conc. $\mathrm{HNO}_{3}$ (4.4 mol. equiv.), acetic anhydride $\mathrm{RT}, \mathrm{ON}$; c) $\mathrm{NaHCO}_{3}(0.2$ mol. equiv.), tetra-butyl ammonium chloride TBACl ( 0.66 mol. equiv.), Sodium dithionite ( 2.3 mol. equiv.), DCM, water, rt, 2 h; d) DMF.DMA (1.2 mol. Equiv.), microwave (max. power $400 \mathrm{~W}$ ), $70{ }^{\circ} \mathrm{C}, 45 \mathrm{~min}$; e) TFA, $70{ }^{\circ} \mathrm{C}, 45 \mathrm{~min}$; f) tertbutyl 4-((tosyloxy)methyl)piperidine-1-carboxylate V14 (1.1 mol. equiv.), cesium carbonate (2.5 mol. equiv.), ACN, reflux, $3 \mathrm{~h}$; g) 4-bromo-2-fluoroaniline $\mathbf{8} 8$ (1.1 mol. equiv.), acetic acid $130{ }^{\circ} \mathrm{C}, 1 \mathrm{~h}$; h) TFA (12.5 mol. equiv.), DCM, RT, $2 \mathrm{~h}$; i) acetic acid (1.2 mol. equiv.), sodium triacetoxyborohydride (1.4 mol. equiv.), formic acid (1.3 mol. equiv.), MeOH:DCM (2:1), RT, 2 h.

Scheme 17. Synthesis of vandetib (V).

The quinazoline motif has been further explored for more potent anticancer agents and sapitinib $\mathbf{S}$ (AZD8931) is being studied as a more potent ATP competitive inhibitor of EGFR and erbB2. Compared to gefitinib or erbB2 inhibitors, AZD8931 was a much more potent inhibitor of EGF-driven cellular proliferation in multiple tumour cell lines ${ }^{46}$ William et al. reported an industrial scale synthesis using Dimroth rearrangement route as has been shown to be utilized to some of commercially available drug of this series. ${ }^{47}$

All in all, Dimroth Rearrangement is the most versatile method to synthesize amino quinazoline derivatives. A general synthetic approach for isolation of such compounds is depicted in Scheme 18. 


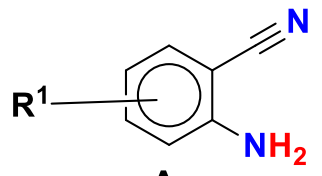

A
DMF.DMA

Reflux

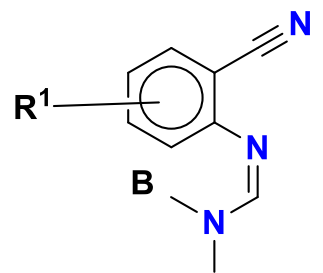

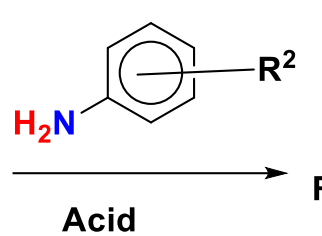

Dimroth Rearrangement<smiles>Cc1ccc2c(Nc3ccccc3)ncnc2c1</smiles>

Scheme 18. General approach for synthesis of amino quinazoline.

Therefore, it is worth to mention general mechanism of Dimroth Rearrangement for such derivatives which is given in Figure 9.

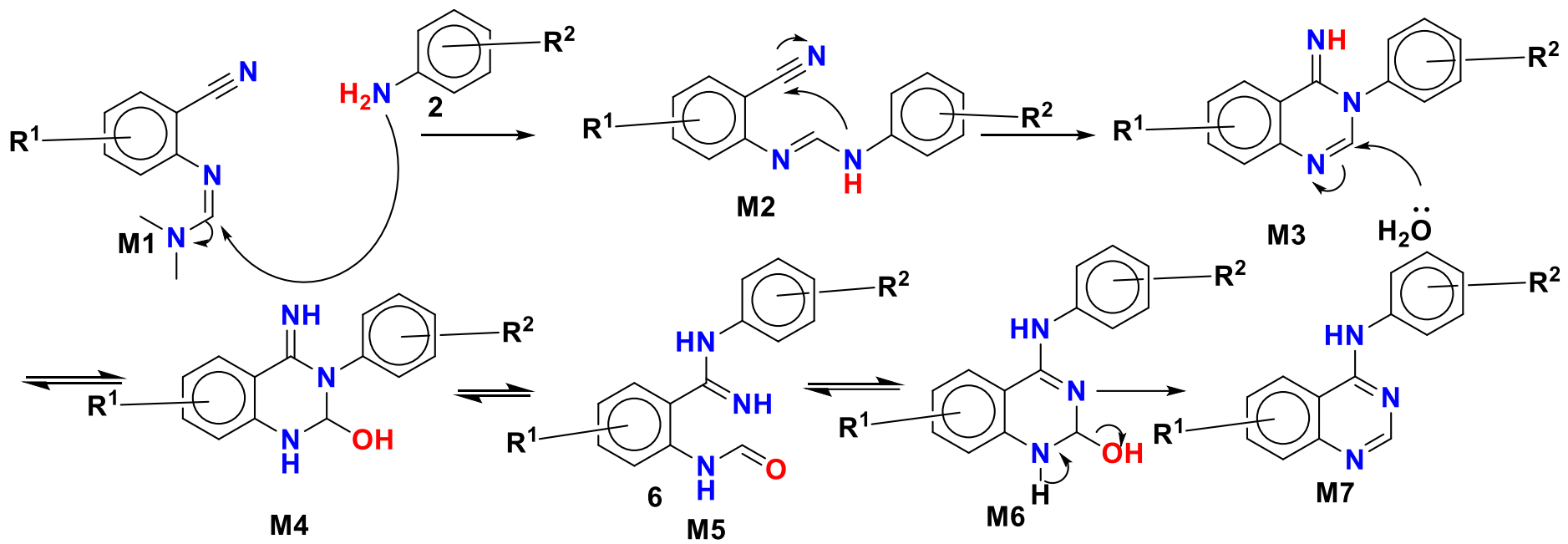

Figure 9. Mechanism of Dimroth Rearrangement.

\subsection{Future perspective of quinazoline based heterocyclic compounds}

Since quinazoline motif is highly prevalent in pharmaceutical compounds specifically anti-cancer drugs, novel scaffolds are being synthesized and investigated as biologically active compounds. This motif has broad scope for synthesis of novel compounds due to diverse reactive positions for derivatization. Piperazine based quinazoline derivatives have been reported recently, which are being investigated preventing neurodegenerative diseases such as Parkinson's disease (PD). ${ }^{48} \mathrm{~V}$. K. Sharma et al recently reported efficient and versatile one-pot sequential synthesis of quinazolin-8-ol derivatives employing heterogeneous catalyst for S-M coupling. ${ }^{49}$

\section{Conclusions}

This review of literature summarizes several synthetic methods for industrial and small-scale quinazoline based anti-cancer drugs. The use of quinazolines for the treatment of various diseases has motivated researchers to improve synthetic approaches and overcome challenges of industrial-scale synthesis. There is a variety of strategies developed for synthesis of such drugs, but the Dimroth rearrangement dominates the 
synthetic chemistry toolbox to produce aminoquinazoline derivatives specifically for industrial scale. The reported syntheses of quinazoline based anti-cancer drugs majorly illustrates the efforts toward efficient and cost-effective approaches which may be utilized for further development or synthesis of novel biologically active derivatives.

\section{Acknowledgements}

We acknowledge Amity Institute of Applied Sciences, Amity University, Sector-125, Noida, Uttar Pradesh, India for the facilities extended during the course of this work.

\section{References}

1. Bowen, J. P.; Zhong, H. A.; Current Topics in Medicinal Chemistry 2016, 16 (9), 897 https://doi.org/10.2174/1568026616999151029114013

2. Armarego, W. L. F.; Quinazolines. Advances in Heterocyclic Chemistry 1963, 1, 253-309. https://doi.org/10.1016/S0065-2725(08)60527-9

3. Nett, M.; Hertweck, C. J. Nat. Prod. 2011, 74, 2265-2268. https://doi.org/10.1021/np2002513

4. Jao, C. W.; Lin, W. C.; Wu, Y.T.; Wu, P. L. J. Nat. Prod. 2008, 71, 1275-1279. https://doi.org/10.1021/np800064w

5. Jafari, E.; Khajouei, M. R.; Hassanzadeh, F.; Hakimelahi, G. H.; Khodarahmi, G. A. Res Pharm Sci. 2016, 11(1), 1-14.

6. Cao, S. L.; Feng, Y. P.; Jiang, Y. Y.; Liu, S. Y.; Ding, G. Y.; Li, R. T. Bioorg. Med. Chem. Lett. 2005, 15, 19151917.

https://doi.org/10.1016/i.bmcl.2005.01.083

7. Giri, R. S.; Thaker, H. M.; Giordano, T.; Williams, J.; Rogers, D.; Sudersanam, V.; Vasu, K. K. Eur. J. Med. Chem. 2009, 44(5), 2184-9. https://doi.org/10.1016/i.ejmech.2008.10.031

8. Jatav, V.; Mishra, P.; Kashaw, S; Stables, J. P. Eur. J. Med. Chem. 2008, 43(9):1945-54. https://doi.org/10.1016/i.ejmech.2007.12.003

9. Xia, Y.; Yang, Z. Y.; Hour, M. J.; Kuo, S. C.; Xia, P.; Bastow, K. F.; Nakanishi, Y.; Namrpoothiri, P.; Hackl, T.; Hamel, E.; Lee, H. K. Bioorg. Med. Chem. Lett. 2001, 11(9),1193-6.

https://doi.org/10.1016/S0960-894X(01)00190-1

10. Ravez, S.; Castillo-Aguilera, O.; Depreux, P.; Goossens, L. Opin. Ther. Patents 2015, 25(7), 1-16. https://doi.org/10.1517/13543776.2015.1039512

11. Kalyankrishna, S.; Grandis, J. R. Journal of Clinical Oncology 2006, 24(17), 2666-2672. https://doi.org/10.1200/JCO.2005.04.8306

12. El-Rayes, B. F.; Lo-Russo, P. M. British journal of cancer 2004, 91(3), 418-424. https://doi.org/10.1038/sj.bjc.6601921

13. Afatinib, https://go.drugbank.com/drugs/DB08916.

14. Dungo; Rosselle T.; Keating, Gillian, M. Drugs 2013, 73(13), 1503-1515. https://doi.org/10.1007/s40265-013-0111-6 
15. Xuenong, X. U.; Patent WO 2014/180271 A/ 2014.

16. Himmelsbach, F.; Langkopf, E.; Blech, S.; Jung, B.; Baum, E.; Solca, F.; Patent WO2002050043A, 2002.

17. Thomas, S.; Florian, C.; Stefan, P.; Patent CA2483590, 2003.

18. Gefitinib, https://www.drugbank.ca/drugs/DB00317.

19. Hopkinson, G. K. Patent USO05770599A, 1998.

20. Barker, A.; Patent EP0566226 1993.

21. Knesl, P.; Roseling, D.; Jordis, U. Molecules 2006, 11(4), 286 - 297. https://doi.org/10.3390/11040286

22. Chandregowda, V.; Venkateshwara Rao, G.; Chandrasekhara Reddy, G. Heterocycles 2007, 71(1), 39-48. https://doi.org/10.3987/COM-06-10884

23. Chandregowda, V.; Venkateswara Rao, G.; Chandrasekara Reddy, G. Organic Process Research \& Development 2007, 11, 813-816. https://doi.org/10.1021/op700054p

24. Chandrasekhar, M.; Srinivasulu, D.; Seshaiah, K.; Kumar, N. Pharmaceutical Chemistry Journal 2014, 48 (8), 521-525.

https://doi.org/10.1007/s11094-014-1141-4

25. Erlotinib, https://www.drugbank.ca/drugs/DB00530.

26. Schnur, R. C.; Arnold, L. D.; Patent USO5747498A, 1998.

27. Ramanadham, J. P.; Bollepalli, N. R.; Nannapaneni, V. C.; 2009 Patent US2009306377A1.

28. Dacomitinib, https://go.drugbank.com/drugs/DB11963.

29. Rewcastle, G. W.; Palmer, B. D.; Bridges, A. J.; Hollis Showalter, H. D.; Sun, L. Nelson, J.; McMichael, A.; Kraker, A. J.; Fry, W. D.; Denny, W. A. J. Med. Chem. 1996, 39(4), 918-928.

https://doi.org/10.1021/jm950692f

30. Fakhoury, S. A.; Tsenwhei Lee, H.; Schlosser, K. M.; Sexton, K. E.; Tecle, H.; Winters, R. T. 2005, Patent US20050250761 A1.

31. Tsou, H. R.; Mamuya, N.; Johnson, B. D.; Reich, M. F.; Gruber, B. C.; Ye, F.; Nilakantan, R.; Shen, R.; Discafani, C.; DeBlanc, R.; Davis, R.; Koehn, F. E. ; Greenberger, L. M.; Wang, Y. F.; Wissner, A. J. Med. Chem. 2001, 44, 2719-2734. https://doi.org/10.1021/jm0005555

32. Haibo, C.; Bin, X.; Hubin, Z.; Jinpei, Z. Journal of China Pharmaceutical University 2014, 45 (2), $165-169$.

33. Yu, S.; Dirat, O.; ACS Symposium Series 2016, 1239, 235-252.

34. Lapatinib, https://go.drugbank.com/drugs/DB01259.

35. Petrov, K. G.; Zhang, Y. M.; Carter, M.; Cockerill, G. S.; Dickerson, S.; Gauthier, C. A. ; Guo, Y.; Mook, R. A.; Rusnak, D.W.; Walker, A. L.; Wood, E. R.; Lackey, K. E. Bioorg. Med. Chem. Lett. 2006, 16, 4686-4691. https://doi.org/10.1016/j.bmcl.2006.05.090

36. Francesco, F. 2012, Patent EP246875Al.

37. Prasad, R. J.; Rao, B.; Satya, A. K.; Nannapaneni V. C. 2011, Patent US008664389 B2 .

38. Vandetanib, https://go.drugbank.com/drugs/DB05294.

39. Hennequin, L.; Francois, A.; Elaine, S.; Elizabeth, S.; Thomas, A. P. 2000 Patent WO 01/32651 A.

40. Lohmann, J. J.; Hennequin, M. L. F. A.; Thomas, A. P 1997, Patent W097/22596 1997.

41. Thomas, A. P.; Henequin, L. F. A.; Johnstone, C. 1997, Patent WO 97/32856.

42. Thomas, A. P.; Hennequin, L. F. A.; John-Stone, C.; Stokes, E. S. E.; Lohmann, J. J. M.; Clayton, E.; 1998, Patent WO 98/13354. 
43. Baozhong, S.; Xiling, S.; Lili, Y.; Yingyi, W.; Zhaoguo, H.; Xu, G.; Yu, Z. L. X.; Xu, D.; Li, Z.; Yu, X. 2013, CN105541736 A.

44. Hennequin, L. F.; Stokes, E. S. E.; Thomas, A. P.; Johnstone, C.; Ple, P. A.; Ogilvie, D. J.; Dukes, M.; Wedge, S. R.; Kendrew, J.; Curwen, J. O. J. Med. Chem. 2002, 45,1300-1312.

https://doi.org/10.1021/im011022e

45. Brocklesby, K.L.; Waby, J.S.; Cawthorne, C.; Smith, G. Tetrahedron Lett. 2017, 58(15), 1467-1469. https://doi.org/10.1016/j.tetlet.2017.02.082

46. Barlaam, B.; Anderton, J.; Ballard, P.; Bradbury, R. H.; Hennequin L. F. A.; Hickinson, D. M.; Kettle, J. G.; Kirk, G.; Klinowska, T.; Brempt, Christine L.; Trigwell, C.; Vincent, J.; Ogilvie, D. ACS Med. Chem. Lett. 2013, 4 (8), 742-74. https://doi.org/10.1021/ml400146c

47. Goundry, W. R. F.; Boardman, K.; Cunningham, O.; Evans, M.; Jones, M. F.; Millard, K.; Rozada-Sanchez, R.; Sawyer, Y.; Siedlecki, P.; Whitlock, B. Org. Process Res. Dev. 2017, 21, 336-345. https://doi.org/10.1021/acs.oprd.6b00412

48. Liu, L.; Welsh, M. J.; 2020, Patent WO2020092258 A1.

49. Sharma, V. K.; Barde A.; Rattan, S. Synthetic Communications 2020, 50 (19), 2962-2968 https://doi.org/10.1080/00397911.2020.1787450

\section{Authors' Biographies}

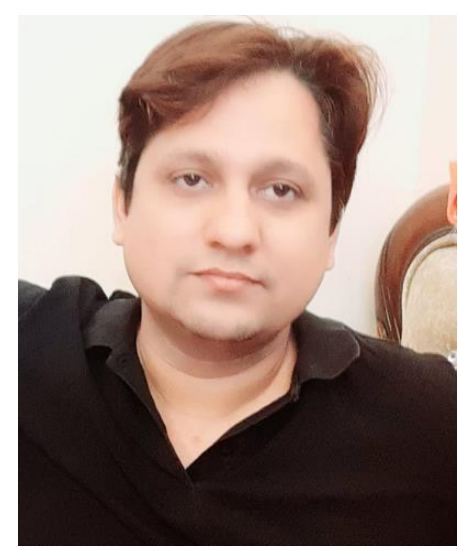

Vijay Kumar Sharma is working as Senior Research Scientist in Integral Bio Sciences Pvt. Ltd, Noida, India. He has worked as medicinal chemist for various collaborators and actively involved in synthesis of novel scaffolds on $\mathrm{mg}$ to gram scale. He has extensive experience of over 13 years in this area and worked with premier organizations such as Ranbaxy Laboratories, Gurugram, India (now Sun Pharmaceutical Industries Limited) and Jubilant Chemsys Limited Noida, India. He has recieved his PhD in Chemistry from Amity University Uttar Pradesh, Sector-125, Noida, India in 2021. He has completed M.Sc. in Pharmaceutical Chemistry (Applied Chemistry) from Guru Nanak Dev University Amrtisar, India in 2007. 


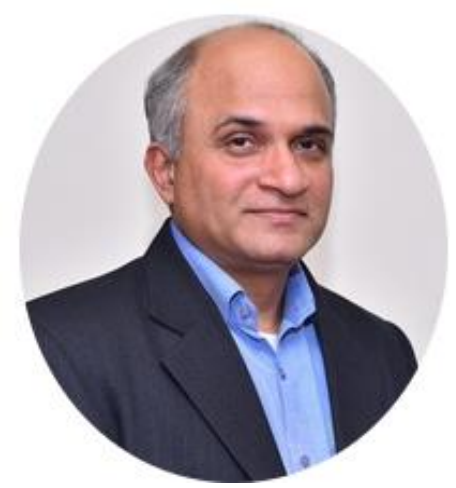

Anup Barde is working as a Director (Chemistry) in Integral BioSciences Pvt. Ltd. (IBS) since May 2013. Prior to IBS he worked with Sai Life Sciences Pune, India from 2007-2013 as Senior Director (Chemistry). Prior to Sai LifeSciences he has worked with Emcure Pharmaceuticals, Pune (2003-2007), USV Limited, Mumbai, India (2000-2003) and FDC Limited, Mumbai (1996-2000). He has extensive experience in scale-up of compounds from gram scale to technology transfer for manufacturing. He has supported the DMF filings for several APIs and has also supported the Pre-Approval Inspections for US-FDA approval. He has completed his Masters in Organic Chemistry in 1992 from D.G. Ruparel College from Mumbai University, India and received his PhD in Organic Chemistry from Haffkine Institute, Mumbai in 1996.

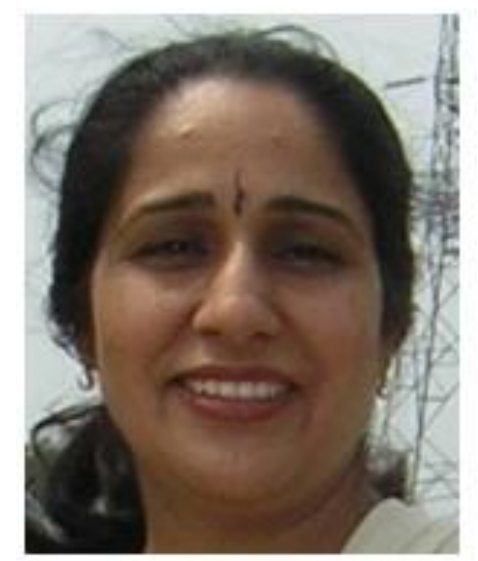

Prof. Sunita Rattan is working as Director in Amity Institute of Applied Sciences, Amity University Uttar Pradesh, Sector-125, Noida, India. She has more than 20 years of teaching and administrative experience in the field of chemistry. She has published more than 60 papers in peer reviewed journals, inventor of more than 10 patents and published 8 books. She has completed her Master degree (1988), M. Phil. (1989) and Ph.D. (1994) in Chemistry from Himachal Pradesh University Shimla, India. Her research interests focus on multidisciplinary aspects of organic chemistry. 